\title{
АЛЬТРУИЗМ И ЭГОИЗМ С ЕСТЕСТВЕННОНАУЧНОЙ ТОЧКИ ЗРЕНИЯ И.Г. Лаверычева
}

\author{
Санкт-Петербургский государственный морской технический университет, Санкт-Петербург, Россия \\ Эл.nочma: ilav65@mail.ru \\ Статья поступила в редакиию 29.04.2016; принята к печати 12.08.2016
}

Статья представляет собой обзор современной литературы в области философской антропологии, социобиологии и психогенетики, раскрывающей общий социально-биологический смысл альтруизма и эгоизма, биологическое происхождение этих свойств и их адаптивное эволюционное значение у животных и человека. Эгоизм необходим в борьбе за существование как стратегия, обеспечивающая в процессе естественного отбора собственное выживание особи, в связи с чем он проявляется в преобладающих тенденциях поведения. Альтруизм - способность заботиться о других и даже жертвовать собой ради других, способствует продолжению рода, а также благополучию и выживанию сообщества в целом. Альтруизм коренится в заботе о потомстве и возникает в эволюции как самый продвинутый вариант стратегии репродуктивного поведения. Эгоизм и альтруизм - противоположно направленные эволюционно стабильные поведенческие стратегии, создающие баланс поведенческих реакций, влияющих на выживание отдельных особей и их сообществ соответственно, - играют ключевую роль в эволюции социальных отношений. Оба этих свойства связаны с вазопрессинокситоциновой регуляцией работы мозга, подконтрольной единому механизму психогенетической наследственности. Проявления эгоизма большей частью происходят без участия сознания, автоматически; проявления альтруизма связаны с более развитыми формами высшей нервной деятельности. В поведении животных и человека в отношениях между эгоизмом и альтруизмом проявляется естественный дуализм, поскольку каждая особь должна выживать и как отдельный организм (для этого необходим эгоизм), и как член сообщества (для этого необходм альтруизм). Но в реальности любое сообщество генетически неоднородно, и у подавляющего большинства особей преобладают эгоистические реакции, в то время как альтруизм устойчиво преобладает у меньшинства.

Ключевые слова: альтруизм, эгоизм, эволючионно стабильные поведенческие стратегии.

\section{ALTRUISM AND EGOISM FROM THE POINT OF VIEW OF THE NATURAL SCIENCES \\ I.G. Laverycheva \\ Saint-Petersburg State Marine Technical University, Saint Petersburg, Russia \\ E-mail:ilav65@mail.ru}

The up-to-date literature on philosophical anthropology, sociobiology and psychogenetics is reviewed to show how the general sociobiological meaning of altruism and egoism and their biological origins and adaptive evolutionary significance are currently treated. Egoism is regarded as necessary for survival of an individual in the struggle for existence and, therefore, as a dominant behavioral strategy. Altruism, the ability to care for others up to self-sacrificing for their sake, helps in procreation and in wellbeing and survival of a population and thus is a variant of the reproductive behavior. Altruism, which is rooted in care for offspring, is the most advanced form of behavioral strategies related to reproduction. Egoism and altruism as evolutionarily conserved strategies, which are pivotal for the survival of individuals and communities, respectively, play a key role in the evolution of sociality. Both traits are associated with the oxytocin-vasopressin regulation of brain functions, which is determined genetically. Egoism is largely manifested unconsciously, whereas the forms of the higher nervous activity involved in the altruistic responses are more elaborate. In the behavior of animals and humans, the relationships between egoism and altruism are a manifestation of the natural duality, since every individual has to survive as such (egoism is required) and as a part of a community (altruism is required). In reality, any community, population, or society is not genetically homogenous, the majority of its members being predominantly egoistic, whereas only a minority is overtly altruistic.

Keywords: altruism, egoism, evolutionarily conserved behavioral strategies.

\section{1. Необходимость синтеза философских и социобиологических знаний}

Современное естествознание располагает достаточно убедительными данными о том, что у людей под влиянием индивидуальных наследственных факторов и различных социально-культурных, социальнобиологических условий формируются два основных нравственно-психологических типа: эгоисты и неэгоисты (альтруисты), причем эгоисты составляют подавляющее большинство [91, 92]. Молекулярно-генетические исследования позволяют выявить лиц со смешанным генотипом, обладающих генами, предрасполагающими к проявлениям как эгоизма, так и альтруизма в зависимости от ситуации и воспитания [88]. Наибольшим вниманием в генетике поведения сегодня пользуются работы, посвященные изучению просоциальности, то есть позитивных эмоций, намерений и поступков в отношении других людей. Установлено, что индивидуальные различия здесь появляются очень рано, в самом начале в жизни. Влияние наследственности на свойства просоциальности возрастает по мере развития детей и связано с вариациями генов, регулирующих нейромедиаторные системы, которые играют центральную роль в приобретении социального опыта, обеспечивая восприятие социальных факторов, их познание и соответствующее адаптивное поведение [108]. Однако значение результатов естественнонаучных исследований и возможности их применения еще недостаточно ясны и нуждаются в надэмпирическом - социокультурном осмыслении.

В то же время и недостатки, и достоинства всех философских построений вокруг вопроса о сущно- 
сти и происхождении эгоизма и альтруизма обнаруживают сегодня, прежде всего, недостаточность биологических знаний о человеке и необходимость развития философской теории эгоизма и альтруизма в естественнонаучном направлении.

Интерес к теоретическому изучению эгоизма и альтруизма стал смещаться из области чисто философского знания в область естествознания еще в начале XX в., когда зарождался новый комплекс биологических наук (этология, экология, зоопсихология, нейропсихология, генетика и психогенетика), связанных с изучением психики человека и его социальных отношений, который сегодня включают в понятие социобиологии. «Объяснить человека в терминах биологии, безусловно, нельзя. Но человек не может быть объяснен и как “чисто" социально-гуманитарный, оторванный от биологического феномен. Поэтому в процессе разработки путей дополнительности биологического и социогуманитарного знания возникает необходимость введения новых понятий и аспектов рассмотрения данной проблемы» [61, с. 186].

Конечно, биологическая природа человека не игнорируется философией. Например, уже более столетия повышенным интересом пользуется психоаналитическая теория 3. Фрейда, которая в поведении человека признает приоритет бессознательного сексуального мотива [82]. Непреходящая заслуга Фрейда заключается в том, что он дал естественнонаучное объяснение самым таинственным, неподконтрольным разуму психическим явлениям, в частности вытеснению и перенесению актуального образа [83]. Однако его теория могла лишь отчасти объяснять проявления крайнего, патологического эгоизма. Альтруистические же, то есть нравственные отношения рассматривались лишь в аспекте аномального развития личности как причина противоестественных и болезненных психических состояний. Поэтому теория Фрейда зачастую используется не столько для объяснения происхождения и роли нормативной морали, сколько для обоснования ее принципиального отрицания [7, 86, 94]. Акцент на сексуальном, как и на любом другом аспекте человеческой жизни, обнажает кризис социальности человека в его сегодняшнем бытии, связанный с уходом от естественно необходимых и нормативно закрепленных культурой родовых отношений [58, с. 5-6]. Социобиология предпринимает сегодня более реалистический и уравновешенный подход к изучению полового диморфизма и связанной с ним социальнопсихической детерминации не только в плане конфликтной реализации сексуального инстинкта, но и во всей полноте подчиненных цели репродукции социально-психических отношений, включая такие не менее значимые проявления, как забота о потомстве, иерархичность, когнитивность, индивидуализм и коллективизм, эгоизм и альтруизм.

Еще не так давно (в 1970-1980-х гг.) труды социобиологов вызывали неприятие и критику специалистов гуманитарных наук, философов, психологов и социологов, поскольку эволюционный подход в этологии и социологии в конце XIX в. оказался серьезно дискредитирован социальным учением Герберта Спенсера. Его позитивистская «Синтетическая философия» [76] талантливо резюмировала достижения науки и распространяла принцип эволюционизма на все существующие области знания (включая этногра- фию, психологию, социологию, культуру и религию). Однако социобиологические представления Спенсера о развития человечества были чрезмерно упрощенными и воспринимались как метафизический редукционизм и «вульгарный социал-дарвинизм».

Спустя 100 лет новый социобиологический подход, в котором ведущая роль, как и прежде, принадлежит эволюционному принципу, сначала по инерции был воспринят как рецидив социального редукционизма. Социобиологические концепции у многих ассоциировались с биополитическими спекуляциями евгеников, расистов и нацистов, когда-то питавших идеи фашизма, заслуженно вызывая негативную реакцию ученых во всем мире. Некоторые философы и сегодня полагают, что главные виновники нравственного релятивизма - биологическое просвещение и дарвинизм и что «отсутствие моральных абсолютов» является «основным этическим последствием эволюционного мышления» [70]. Но время показало, что современная социобиология, изучающая объективные закономерности нравственного и социальнокультурного развития человека, не только лишена идеологической предвзятости, но и достаточно убедительна. Она открывает новые перспективные направления для научных исследований, и интерес к ее концепциям у специалистов не только естественнонаучного, но и гуманитарного профиля - философов, психологов и социологов - сегодня неуклонно растет.

Согласно определению, данному основоположником социобиологической теории поведения животных и человека Э. Уилсоном, социобиология представляет собой «распространение принципов популяционной биологии и эволюционной теории на социальную организацию» $[130$, p. X]. Преодолевая как жесткий «генетический» детерминизм, так и умозрительные представления об универсальной пластичности человека, Ч. Ламсден и Э. Уилсон разработали многоуровневую модель взаимодействий генов и культуры, объясняющую не только биологические особенности популяций (этносов), но и эволюцию процесса познания, мышления и культуры [115]. Связь от генов - к культуре, по их модели, опосредуется двумя промежуточными уровнями: уровнем клеточного развития организма, в частности, клеток нервных тканей, которое подчинено генетической детерминации, и уровнем когнитивного развития, зависящего, в первую очередь, от условий среды, в частности, социальной культуры. Кроме того, согласно теории геннокультурной коэволюции, существует и обратная связь: от культуры - к генам [43, 44].

Влияние социального поведения, связанного с условиями внешней среды, на состояние и функционирование генов и, следовательно, возможность такого влияния на сам ход дальнейшей эволюции подтверждены целым рядом работ последнего десятилетия по молекулярной биологии [53].

Антропологи, опираясь на мнение психологов, обычно подчеркивают, что «инстинктивная запрограммированность» у человека выражена гораздо слабей, чем у животных. Э. Фромм считал, что человек изначально «в своем поведении... руководствовался инстинктами лишь в незначительной мере»: «При всем многообразии точек зрения на инстинкты почти все исследователи приходят к единому выводу: чем выше уровень развития живого существа, тем меньшую роль в его жизни играют жесткие 
филогенетически заложенные модели поведения» $[85$, с. $184-185]$.

Действительно, репродуктивное поведение большинства беспозвоночных, скажем, насекомых, паукообразных, ракообразных, имеет гораздо более жесткую генетическую детерминацию, чем репродуктивное поведение высших позвоночных - птиц и млекопитающих. Однако это не значит, что инстинкты у птиц и млекопитающих менее выражены или играют менее важную роль. Современные этологи, нейрофизиологи и зоопсихологи полагают, что повышение уровня общей организации сопровождается развитием не только когнитивных функций, но и обслуживаемых когнитивным аппаратом базовых инстинктивных программ (в том числе программ отчасти инстинктивного, отчасти средообусловленного поведения). Роль инстинктов в жизни человека не может быть меньше, чем в жизни животных, - это противоречило бы законам физиологии и эволюции. Более того, по замечанию Лоренца, «можно предполагать, что подлинно инстинктивных стимулов у него не меньше, а больше, чем у любого животного» $[47$, c. 8$]$

То, что поведение человека гораздо пластичней и располагает самой сложной или свободной системой выбора поведенческих реакций, говорит лишь о том, что он значительно превосходит животных в развитии когнитивных функций, то есть высших отделов коры головного мозга, выполняющих самые быстрые и комплексные - интегральные регулятивные функции. Когнитивные преимущества человека бесспорны, и именно они накладывают на его образ жизни кардинальные отличия. Альтернативные формы поведения людей и их конкретные мыслительные стереотипы генетически НЕ обусловлены - они развиваются на основе информации, приобретенной в процессе социализации (исключительно разнообразные впечатления, подражание, воспитание, обучение, образование и самообразование, сложный жизненный опыт). Но это не значит, что отделы, ответственные за удовлетворение инстинктивных потребностей, остаются недоразвитыми. Человек всегда остается под властью биологических ограничений, мышление лишь помогает ему находить в этих естественных пределах оптимальные пути.

Исходя из данных нейробиологии, когнитивной психологии и культурной антропологии, социобиологи полагают, что человеческая культура формируется когнитивными механизмами, которые, хотя содержательно и не детерминируются генами, но все же исходно запускаются ими. Благодаря участию когнитивных функций генетическая эволюция расширяет воздействие среды на человека до уровня культуры и макросоциальной организации. С другой стороны, «сознание - это культурное образование, которое вне культуры, вне символической деятельности и общения просто не существует, и в этом смысле сознание связано с бытованием определенных нормативных символических систем» [51, с. 59].

В философской антропологии подчеркивается, что человек не рождается человеком - он им становится: «Что такое человек и кем он должен стать - эту загадку каждая историческая эпоха решает по-своему. Разумеется, существуют традиции, которых люди должны придерживаться, чтобы выжить в ходе инноваций, однако именно изменения окружающего мира заставляют искать новые возможности самоосуществления... Он всему должен научиться... Каждый человек самостоятельно накапливает знания и опыт, но этот процесс освоения знаний, технических навыков и культурных ценностей обеспечивается не наследственным путем и не непосредственной передачей из рук в руки, ... . с специальными институтами образования. И чем раньше человек приобщается к культуре, тем полнее и глубже он ее постигает. ...Отсюда вопрос о культурном наследии и научении приобретает фундаментальное значение» [57, с. 17].

Соответственно, человек должен не только учиться быть нравственным, но и стремиться к выяснению и созданию условий, в которых это умение, как и возможность обучения, могут быть максимально реализованы. Несомненно, наиболее приоритетными для нравственного воспитания личности являются социально-культурные условия, специально создаваемые в обществе для научения тому, каким должен быть человек. При этом суть происхождения «культуры может быть сформулирована и в социобиологических терминах: человеческая культура эволюционировала в течение длительного периода, пройдя через множество различных стадий, и то, что сегодня существует как культура, представляет собой сплав различных компонентов адаптивных стратегий... которые доказали свою плодотворность в прошлом» [75, с. 129]. При этом инновационная роль социальнокультурных факторов не устраняет, а дополняет консерватизм биосоциальных процессов [11]. Как взаимодействуют оба вида факторов и каковы результаты этого взаимодействия - еще во многом предстоит уточнять.

\section{2. Альтруизм в теории эволюционно стабильных стратегий поведения}

\section{Наследственно-адаптивный смысл стратегии поведения}

Краеугольным камнем современной этологии и, в частности, социобиологических теорий поведения человека является теория Дарвина о происхождении видов путем естественного отбора (1859) и теория происхождения человека (1871). Но особенно важны для этологического направления исследований дарвиновские работы о выражении чувств и эмоций у человека и животных (1872) [17].

Общий тезис теории эволюции и поведенческой биологии состоит в том, что способы поведения у животных и людей подчинены одним и тем же законам эволюции, поскольку они как живые организмы обладают общими морфологическими и физиологическими чертами. При этом естественный отбор действует, прежде всего, через изменение частоты актов размножения различных вариантов вида. Базовую концепцию эволюционной теории поведения, по Х. Харбаху [89], можно свести к следующим положениям.

1. В результате взаимодействия генотипа и окружающего мира формируются не только внешние черты организма, но и его поведение.

2. Поведение проявляется фенотипически, как и любой другой признак.

3. Существуют типы поведения, которые вписаны в целостный генотип.

4. Из чего вытекает, что типы поведения, как правило, адаптивны. 
По мнению Харбаха, исследования, проведенные в XX в., особенно открытия в генетике, частично модифицировали гипотезу Дарвина и, вместе с тем, существенно укрепили ее. Они показали, что «новая поведенческая биология, объединяющая этологические и социобиологические подходы, способна продуцировать плодотворные частные теории о социальном поведении животных и человека» [89, с. 38].

Сегодня не только биологи-этологи, но и специалисты в области медицинской биологии признают, что если «классическая эволюционная теория использовала в качестве критериев исторического родства главным образом морфологические признаки», то «современная этология доказала, что не менее надежными в установлении филогенетического родства являются особенности поведения» [6, с. 288].

Этологами установлено, что существуют определенные типы устойчивого врожденного поведения, свойственные определенному уровню организации: либо данному виду организмов, либо - многим видам и более крупным таксономическим единицам. Такие типы поведения, имеющие определенную генетическую детерминацию, были названы Джоном Мэйнардом Смитом эволюционно стабильными поведенческими стратегиями $[117,118]$. Сегодня есть все основания полагать, что проявления альтруизма и эгоизма у человека являются определенной формой поведенческой стратегии, которая достаточно широко представлена в животном мире.

Говоря о единой природной сущности солидарности и взаимопомощи человека, а также многих, в особенности, высших животных как об эволюционной адаптации поведения к социальному образу жизни, П.А. Кропоткин более чем на полвека опередил современных социобиологов и фактически первым раскрыл сущность альтруизма и эгоизма человека как эволюционной поведенческой стратегии [38, 39]. Сегодня идеи Кропоткина получают этологическое и психогенетическое подтверждение. Правда, это не относится к его утверждению о том, что альтруизм в социальной жизни обязательно доминирует над эгоизмом и что решающим фактором социальной эволюции внутри вида является не борьба за существование в виде конкуренции организмов (как, по преимуществу, думал Дарвин), а борьба за существование в виде сотрудничества и взаимопомощи. Вместе с тем, не только у разных видов животных организмов, но и внутри одного вида, например, у человека, склонность к альтруизму или эгоизму проявляется по-разному, что не всегда находит объяснение.

Существуют различные виды поведенческих стратегий: например, у многих животных в популяциях выделяются специализированные поведенческие группы, различающиеся по таким признакам, как особенности питания, специфика суточной активности, поисковое, охранное, территориальное и ориентировочное поведение, ярусное распределение и т. п. Как отмечает Ж.И. Резникова, в популяциях многих видов присутствует определенное соотношение носителей различных, генетически предопределенных, стратегий поведения. Вместе с тем, в зависимости от ситуации особь может вести себя в сообществе то как кроткий примиренец («голубь»), то как агрессор («ястреб»), а также как «вор», «насильник», «дон-жуан» и т. п. Поскольку условия доступа к ресурсам (в том числе и к репродуктивным) для носителей раз- ных стратегий складываются по-разному, равновесие между альтернативными стратегиями бывает напряженным. В поведенческом плане каждая особь может всю жизнь выступать как «актер одной роли», но может использовать и смешанную стратегию, например, выступать то в роли «ястреба», будучи хозяином территории, то в роли «голубя», попадая в ситуацию пришельца [68].

\section{Репродуктивные стратегии}

Наиболее важным в организации социальной жизни животных является поведение, связанное с размножением, которое наследственно регулируется репродуктивными стратегиями поведения.

Классический пример особой репродуктивной поведенческой стратегии - клепторепродуктивная стратегия, характерная для определенной части самцов некоторых видов, устраивающих турниры в борьбе за внимание самки, - в частности, у благородных оленей, турухтанов, тетеревов. Во время турнира, пока «добропорядочный» хозяин гарема честно сражается с другим, не менее «мужественным», но не имеющим должного статуса самцом, «бессовестные» самцы-клептостратеги, а попросту «сексуальные воры», прячутся в кустах и тайком успешно спариваются с самками. Клептостратег может оставить не меньше потомства, чем владелец гарема, и к тому же значительно меньше рискует получить повреждения от схваток с соперниками. Между носителями разных стратегий в популяциях сохраняется динамическое равновесие, и ни одна из них не «захватывает» популяцию полностью.

Аналогичная эволюционно стабильная стратегия выявлена и в популяциях ящериц Uta stansburiana, обитающих в Калифорнии $[68,124]$. Она реализуется самцами, принадлежащими к трем морфотипам, которые различаются цветом пятна на горле: оранжевым, голубым или желтым.

Голубогорлые моногамные самцы демонстрируют самое «добропорядочное» поведение. Они защищают нору и единственную избранницу на своей территории. Это обеспечивает гарантированный минимум популяций. Кроме того, данная стратегия обеспечивает наилучшую позиционную защиту уже оплодотворенной самке и потомству (активная забота о потомстве для пресмыкающихся, в отличие от птиц, млекопитающих и даже многих амфибий, не характерна).

Оранжевогорлые полигамные самцы имеют самый высокий уровень тестостерона в крови и являются самыми агрессивными. Они пытаются охранять гарем на обширной территории. У них больше всего возможностей для спаривания, но меньше гарантий, и позиционная защита оплодотворенных самок, как и потомства, значительно ниже, чем у моногамных самцов

Желтогорлые ведут себя как «донжуаны». Они не имеют ни своей территории, ни своих самок, однако оставляют заметное число потомков, используя стратегию воровства копуляций. Проникая на территорию оранжевогорлых самцов, желтогорлые используют поведенческую мимикрию. Они притворяются самками, которые в данный момент не интересуются спариванием. Обман подкрепляется «самочьими» ритуальными движениями, которые вводят в заблуждение хозяев территории. Эта стратегия успешна в отношении спаривания. Но позиционная защита 
оплодотворенных самок и потомства в этом случае минимальна.

По замечанию Ж.И. Резниковой, данный пример демонстрирует «в буквальном смысле тщательно расписанные роли для всех участников эволюционной пьесы: по цвету пятна на горле ящерицы наблюдатель с высокой точностью может предсказать поведение животного практически во всех жизненных ситуациях» [68, с. 298].

Аналогичные поведенческие стратегии можно рассматривать и как социобиологические основания для формирования различных систем брачных отношений в этногенезе человека: полигамии, закрепленной в культуре арабского Востока, и моногамии, характерной для европейской цивилизации. В обеих цивилизациях присутствует и промежуточная стратегия «воровства», которую культурная традиция и мораль отвергают, поскольку она, хотя и адаптирована к системе брачных отношений, все же направлена на разрушение брака. С позиции альтруистической нравственности, основанной на принципе сострадательности и вытекающего из него запрета на насилие в сфере родовых отношений, направленного, прежде всего, против женского рабства, моногамия является наиболее прогрессивной формой брака. Прогрессивность моногамии утверждается и как более справедливые и доброжелательные отношения между детьми, рожденными и воспитанными одной парой родителей в условиях постоянной моногамной семьи. Моногамные отношения исключают те крайние проявления обиды, зависти и вражды, которые нередко возникают между детьми, рожденными от одного отца и разных матерей. Как показывает история, именно социально-биологической стратегии моногамии соответствует не только антично-христианская мораль альтруизма, но и самая эффективная система экономических отношений, построенная на труде, максимально свободном от принуждения. Таким образом, вопрос о роли социально-биологических стратегий в жизни человека и человечества, преломляясь с отношением альтруизма и эгоизма, имеет не только нравственное, но и политическое значение.

\section{Стратегия непотизма: родственный альтруизм}

Сущность биологической жизни - размножение. Индивидуальная жизнедеятельность животных на всех уровнях ее организации подчинена главной цели - дать и обеспечить потомство, а естественные социальные отношения складываются так, чтобы обеспечить наиболее эффективную заботу о нем. Этот важный биологический принцип и то, что важнейшей поведенческой стратегией является родительский альтруизм, наиболее ярко и убедительно показал Н. Тинберген [80]. Родительский альтруизм проявляется у многих птиц и млекопитающих в постоянной заботе о детях и готовности спасать их ценой собственной жизни. Кроме того, коллективному выживанию способствуют и стратегии родственной взаимопомощи, проявляющиеся в покровительстве родственникам, или непотизме (nepos - внук, племянник). Это понятие пришло в этологию животных из социальной жизни человека, где оно издавна применялось для обозначения отношений семейственного протекционизма.

По свидетельству Ж.И. Резниковой, сообщества, в которых наблюдается развитая кооперация, чаще всего представляют собой именно родственные группы. Разумеется, речь идет об автоматических, генетически обусловленных, популяционных процессах, а не о том, что животные «сознательно» рассчитывают на генетическую пользу от помощи родственникам, которая проявится в будущих поколениях. Кооперация в сообществах может принимать такие формы, как непосредственный обмен пищей и помощь в выращивании чужих потомков, доходящая до полного репродуктивного «самопожертвования», то есть отказа от собственного размножения с целью обеспечения воспроизводства близких родственников [68, с. 299]. Коллективное выращивание потомков обнаружено примерно у 300 видов птиц, в числе которых - удоды, сойки, дятлы, медоеды, сорокопуты, крапивники, и 120 видов млекопитающих, включая целые группы видов мангуст, грызунов, землероек, обезьян, псовых и кошачьих. У некоторых видов взаимопомощь выражается в сравнительно простых отношениях: господствующие (высокоранговые) особи не подавляют (или почти не подавляют) репродуктивный потенциал у подчиненных (субординантов). Так, у шакалов, мангуст, львов несколько самок приступают к размножению одновременно. Помощники (обычно старшие сестры и тетки) снабжают их добычей, а самцы охраняют территорию. У многих других видов отношения основаны на узурпации жизненных ресурсов сородичей и на принуждении их к социальной специализации. Но такие отношения не очень устойчивы: помощь высокоранговым особям со стороны низкоранговых зачастую сочетается с конкурентной борьбой помощников за право иметь собственных детей [68, с. 301].

\section{Как объясняет наследование альтруизма теория родственного отбора}

По наблюдениям Ж.И. Резниковой, в колониях диких кроликов при появлении хищника нередко один или несколько кроликов, прежде чем убежать, громко барабанят задними лапками по земле. Благодаря этому сигналу остальные кролики успевают скрыться, хотя «барабанщику» минутная задержка может стоить жизни. Если в колонии у него нет родственников или потомков, гены, которые определяют сигнальное поведение, могут погибнуть вместе с ним. Если же родственников достаточно для того, чтобы это поведение способствовало увеличению совокупной приспособленности, отбор будет благоприятствовать сохранению данных генов. И это не значит, что кролик «барабанщик» сознательно решается пойти на риск и даже пожертвовать собой. Он ведет себя так, как определено его генетической программой. В популяциях обычно бывает достаточно «барабанщиков», то есть особей с явно выраженным сигналом тревоги, так как в группах родственников из поколения в поколение сохраняется достаточно носителей генов, определяющих данное поведение [68, с. 299].

Сохранение в популяции генов альтруиста за счет выживания его родственников Дж. Мэйнард Смит рассматривал как один из механизмов врожденной детерминации определенного типа поведенческих реакций, называемых им эволюционно стабильной поведенческой стратегией [116, 117].

Чтобы объяснить, каким образом сохраняются гены альтруизма в популяции, У.Д. Гамильтон [103] и Дж. Мэйнард Смит [116], опираясь на фундамен- 
тальный труд Р. Фишера «Генетическая теория естественного отбора» [101], предложили теорию родственного отбора. Родственный отбор рассматривался ими как механизм естественного отбора, при котором альтруизм индивида помогает выживать не ему самому, а его детям и ближайшим родственникам, имеющим определенное сходство с ним по генотипу. Как поясняют российские зоологи 3.А. Зорина, И.И. Полетаева и Ж.И. Резникова, альтруизм, с точки зрения Гамильтона, - «такое поведение, в результате которого индивидуальная приспособленность другой особи повышается за счет снижения приспособленности данной особи», и в результате чего, благодаря «отбору родичей альтруиста», увеличивается «совокупная приспособленность» семьи [27].

Гамильтон предложил математическую модель наследования генов альтруизма на основании предположения, что индивид передает $1 / 2$ этих генов детям и сам имеет $1 / 2$ генов, общую с матерью и отцом, а также с братьями и сестрами, $1 / 4$ - общую с племянниками и двоюродными братьями и $1 / 8$ - с двоюродными племянниками [103, 104].

Аналогичные попытки впоследствии предпринимались и другими генетиками. Вывод Гамильтона о том, что альтруизм индивида, хотя и не способствует его собственному выживанию, служит сохранению генофонда и продолжению рода его семьи, имел важное социобиологическое значение. Однако В.П. Эфроимсон подчеркивал, что все предложенные модели, включая модель Гамильтона, «преждевременны, поскольку не выяснены качественные закономерности» $[92$, с. $58-59,75]$.

Проблема разработки модели наследования альтруизма до настоящего времени остается открытой.

\section{Взаимный - реципрокный альтруизм}

Дальнейшие исследования показали, что альтруистические или дружеские отношения можно встретить у особей, состоящих не только в близком, но и в дальнем родстве. Более того, у ряда видов взаимопомощь и альтруистическое поведение устойчиво проявляются и вне родственных связей. Эти отношения получили название взаимного, или реципрокного альтруизма. Понятие взаимного альтруизма было введено Р. Трайверсом: в отличие от родственного альтруизма, реципрокный, или «взаимный», альтруизм предусматривает ту или иную степень самопожертвования даже ради неродственного индивида, если тот готов к аналогичной жертве [127].

В обзоре Резниковой приведен яркий пример реципрокного альтруизма летучих мышей-вампиров Desmodus rotundus, обитающих в тропической Америке [68, с. 302]. Они живут в полых деревьях и вылетают ночью кормиться кровью коров и лошадей. Интенсивность их метаболизма такова, что после двух ночей голодания вампир умирает, если только не выпросит пищу у другой особи. Передача пищи от одного вампира к другому путем срыгивания является чистым альтруизмом, поскольку обеспечивает реципиенту 12 часов жизни, хотя в такой же степени она укорачивает и жизнь донора. Тем не менее, в колонии вампиров было описано неоднократное альтруистическое спасение сытыми голодных, как являющихся, так и не являющихся родственниками. При этом между особями устанавливаются прочные связи. Отмечено, что 12 лет подряд две самки посто- янно устраивались на отдых вместе (продолжительность жизни вампиров составляет до 18 лет). Правда, вольерные эксперименты показали, что обмен пищей все-таки чаще происходит между родственниками, хотя второй круг контактов образуют и просто дружественные («ассоциированные») особи, связанные взаимным грумингом (вылизывание, уход за шерстью партнера).

Несомненно, взаимный альтруизм коренится в родственном альтруизме, то есть в наследственной способности вступать в особо доверительные отношения с родителями и близкими родственниками. Большое значение в отношениях взаимного доверия могут иметь импринтинг и подражание, когда в ранней памяти детеныша или птенца наряду с образами родителей запечатлеваются образы как родственников, так и соседей, которые изначально являются просто менее близкими родственниками, с которыми родители поддерживают добрососедские отношения. Однако не менее очевидно, что взаимный альтруизм связан и с развитием когнитивных функций. Благодаря способности к подражанию и научению взаимный альтруизм может существовать как культурная традиция, но может проявляться и в результате ситуативного предвидения благодаря индивидуальному опыту и прогностической функции мышления. Сегодня теория реципрокного альтруизма успешно развивается в эволюционной экологии с применением подходов и методов теории игр $[20,118,127]$.

\section{Бескорыстный альтруизм.}

В человеческом понимании истинным альтруизмом является поведение, не обусловленное никакими взаимными обязательствами и не связанное с ожиданиями вознаграждения. Обычно оно проявляется как реакция сочувствия, сострадания и стремление помочь без всякого расчета на взаимность. В некоторых случаях эта реакция бывает спонтанной, быстрой и безотчетной, вызванной сиюминутным импульсом сопереживания. Так, например, автоматически мы протягиваем руку поскользнувшемуся на улице незнакомому человеку. В других случаях поступки бескорыстного альтруизма подготавливаются обучением, воспитанием, идеологией, знанием социально одобряемых форм поведения, умением давать нравственные оценки и привычкой руководствоваться нормами морали, умением осознанно принимать решения и делать выбор в соответствии с альтруистической - культурной нравственной установкой. Примером такого поведения могут служить бойцы народного ополчения, которые добровольно отправлялись на фронт Великой Отечественной войны. Возможно объединение безотчетного действия и продуманной нравственной позиции. Так или иначе в человеческом понимании альтруизм связан не только с развитием когнитивных функций человека, но и с развитием нравственной культуры и идеологии как уникальным результатом исторического развития человеческого общества.

\section{3. Значение когнитивных функций} Социальные контакты и умственные способности жсивотных

В рамках теории реципрокного альтруизма Р. Трайверс пытался объяснить эволюционную стабильность дружеских связей или отношений взаимопомощи как 
определенной поведенческой стратегии с помощью теории игр [127]. Взаимодействие в сообществах он рассматривает по аналогии с «рынком услуг». Животные обмениваются пищей и различными «актами благодеяния», например, грумингом или сигналами, предупреждающими об опасности. Демонстрируя готовность к совершению таких актов, животные как бы предлагают себя в качестве партнеров. Но при этом они ведут постоянный «учет и контроль» альтруистических актов, а также возможных ситуаций обмана. Используя игровые модели, Трайверс стремился доказать, что для популяции дружеские отношения более выгодны, чем индивидуалистические. Он был убежден, что способность поддерживать дружеские отношения как у животных, так и у человека имеет генетическую детерминанту. Впоследствии исследование реальных ситуаций, в которых фигурировали, в частности, разные виды приматов, показали, что животные, действительно, проводят больше времени в обществе «честных» партнеров и учитывают вероятность обмана [96].

В последних работах американских нейропсихологов показано, что мозг человека позитивно оценивает благотворительные поступки, независимо от того, совершаются они бескорыстно или по расчету. И в том, и в другом случае возбуждаются одни и те же центры основания больших полушарий (левая передняя островковая доля, левая нижняя часть полосатого тела и передняя поясная кора). Но при этом импульс возбуждения в разных зонах проявляется по-разному и проходит разные пути, то есть мозг хорошо отличает бескорыстный альтруизм от взаимовыгодных отношений $[102,105]$. Полученные данные говорят о единстве происхождения бескорыстных и взаимовыгодных отношений, точнее, о том, что, вероятнее всего, бескорыстный альтруизм произошел от взаимного (реципрокного) альтруизма.

Ж.И. Резникова подчеркивает: «учет и контроль» альтруистических актов, так же как и возможных ситуаций обмана, требуют от участников мобилизации когнитивных функций. Это требует от животных по меньшей мере способностей к запоминанию и формированию ассоциаций между конкретными образами участников отношений и исходящих от них стимулов. К настоящему времени получено немало данных о способности животных к взаимозачету не только благодеяний, но и нанесенного им ущерба, а также способности «планировать» и корректировать поведение по отношению к другим особям своего вида. В сообществах животных, характеризующихся высокой степенью развития психических функций, способности к использованию приобретенных навыков в общественной жизни составляют основу явления, которое называют социальной навигацией. Кроме отношений реципрокного альтруизма, «одним из высших проявлений социальной навигации рассматривается макиавеллизм, то есть умение животных манипулировать другими особями и использовать их как инструменты для достижения собственной цели» [68, с. 302-303].

В качестве составляющих макиавеллизма указывают на способность животных обманывать, а также формировать альянсы для достижения социальных выгод. В экспериментальных работах на приматах описано разделение труда в сообществах, основанное на манипуляциях поведением партнеров. Такое поведение требует от животного сообразительности и социального опыта, оно возникает и развивается в онтогенезе животного постепенно и поэтапно. Различные проявления социальной навигации описаны в сообществах слонов, ворон, галок, дельфинов, высших обезьян и у некоторых других животных $[68,79]$.

Анализ взаимодействия животных в родственных группах показывает, что, хотя непотизм - широко распространенный способ увеличения вклада в генофонд следующего поколения, однако даже при взаимодействии родственников важную роль играет тактика избегания обмана. Таким образом, дружеское общение животных, хотя и не исключает влияния наследственности, в первую очередь выявляет когнитивность контактов и способность к научению, а не исключительно автоматические - врожденные генетические свойства. Процессы обучения и принятия спонтанных решений, содержание которых напрямую не определяется генетическими программами, с точки зрения этологов имеют решающее значение в адаптивном поведении животных [69].

Противоречие между автономностью задатков и диктатом среды во многом снимается новейшими исследованиями нейрофизиологов, обнаружившими в 1990-х гг. в лобных долях переднего мозга высших животных и человека так называемые «зеркальные нейроны» [37], или клетки-имитаторы [95]. Эти нейроны активны у животного или человека как при совершении им собственных движений, так и при наблюдении, когда эти движения совершаются другими. Свойства этих нейронов проливают свет на процессы подражания, играющие первостепенную роль в процессах раннего научения социально адаптированному поведению. В настоящее время, хотя это еще и не получило прямого экспериментального подтверждения, специфической функцией зеркальных клеток мозга объясняют способности понимания чужого сознания и макиавеллиевский интеллект, язык и речь, особенно язык жестов, формирование сложных общественных отношений, в особенности социальную жизнь человека, и, наконец, явление эмпатии как способность понимать эмоции других путем сопереживания. Полагают, что зеркальные нейроны ответственны и за актерское мастерство, освоение метода вчувствования, а также за общее развитие культуры и цивилизации через подражание. С нашей точки зрения, ими же могут запускаться и процессы импринтинга, включающие с помощью ранних впечатлений важнейшие программы развития.

\section{Сравнение умственных способностей жсивотных и человека}

Этологи, нейрофизиологи и эволюционисты едины в своем заключении о том, что нет принципиальных различий в морфологической и нейропсихической организации человека и животных.

В теории высшей нервной деятельности И.П. Павлова давно установлен единый для животных и человека механизм нейрогуморальной - безусловно и условно рефлекторной - регуляции поведения и коммуникации (первая сигнальная система). При этом Павлов считал принципиальным отличие животных от человека в том, что у них нет речевой коммуникации (вторая сигнальная система). Действительно, рассудочную деятельность или элементарное мышление, соответствующее первой сигнальной системе по Павлову, сегодня находят у всех животных, обла- 
дающих произвольной двигательной активностью и мозгом как средством ее управления: «Рассудочная деятельность животных на всех ступенях филогенеза детерминирована уровнем развития мозга, который в свою очередь определяется генотипом животного... В процессе естественного отбора наиболее адекватных форм поведения в многообразно меняющихся условиях среды происходит и отбор тех морфофизиологических особенностей мозга, которые обеспечивают выполнение наиболее адаптивных поведенческих актов» [40, с. 257].

Но у многих животных сегодня обнаруживается и способность общаться на уровне второй сигнальной системы. И для этого у них имеются естественные механизмы коммуникации, аналогичные человеческим, хотя и не такие сложные, как у человека. Это разнообразные (в зависимости от внешней ситуации) звуковые сигналы птиц и млекопитающих, например, дельфинов и слонов, звуки, жесты и мимика обезьян, особые смысловые контакты пчел и муравьев и многие другие формы кодирования и передачи информации $[27,28,66]$. Ошибочной оказалась уверенность многих нейрофизиологов, включая И.П. Павлова, в том, что животные не способны к абстрактному мышлению. Сегодня твердо установлено, что «у животных действительно существуют зачатки мышления как самостоятельная форма когнитивной деятельности. ...Элементы мышления проявляются у животных в разных формах, и диапазон этих проявлений тем шире, чем сложнее по структуре и функциям их мозг. Главная особенность мышления в том, что оно обеспечивает способность животного принимать новое адекватное решение при первой же встрече с необычной ситуацией» [28, заключение].

Разумеется, возможности обучения и способность к абстрагированию даже у наиболее эволюционно «продвинутых» животных значительно уступают возможностям человека. Но в них нет принципиального отличия. По данным, приведенным 3.А. Зориной и И.И. Полетаевой, у самых «сообразительных» животных - врановых, попугаев, дельфинов и человекообразных обезьян - обнаружены принципиально те же элементы мышления, что и у человека: способность к обобщению и абстрагированию, формированию и пониманию символов, самоидентификации и социальным знаниям [28, главы 5-7]. Кроме базовых «естественных понятий», возникающих в результате непосредственного восприятия, характерного для большинства позвоночных животных, у врановых, попугаев, дельфинов и высших обезьян проявляется способность к формированию так называемых довербальных понятий, которые можно отнести к уровню слабо развитого человеческого сознания, соответствующего уму ребенка в возрасте 2-3 лет. У них же выявлена и более сложная организация структуры мозга - цефализация, аналогичная человеческой [28, глава 8].

Поразительные результаты дала серия опытов по воспитанию «говорящих обезьян», которые проводились в США с конца 1960-х гг. по настоящее время. У шимпанзе вида бонобо́ обнаружилась не только способность понимать человеческую речь, но и способность к ее осмысленному использованию в общении с людьми и между собой с помощью языка глухонемых и компьютерной системы воспроизведения звуковой и письменной речи [29].
По заключению М.Л. Бутовской, эта программа исследований «сыграла исключительно важную роль для понимания когнитивных способностей человекообразных обезьян и сняла последние сомнения относительно отсутствия качественной грани между человеком и человекообразными обезьянами. К настоящему времени получены убедительные свидетельства о том, что шимпанзе, гориллы и орангутаны способны осваивать язык глухонемых и обладают выраженными задатками к символическому мышлению. Они способны: формировать внутренние представления о предметах, спонтанно называть предметы, обозначать знаками отсутствующие предметы, создавать новые понятия путем комбинирования известных им знаков, мыслить по аналогии и категориально, употреблять метафоры. Они способны: шутить и обманывать... общаться друг с другом на ручном языке и с помощью компьютера, воспринимать синтетическую речь через наушники, равно как и обучать друг друга языку. ...Несмотря на тот очевидный факт, что в природной среде человекообразные обезьяны не используют символы, их мозг обладает отчетливыми задатками символического мышления» [10, с. 156].

Языковые способности непосредственно связаны с высшими психическими функциями мозга, в первую очередь, со способностью мыслить символически, а также умением скрывать собственные мысли и намерения. Несмотря на то что символическое мышление в развитой форме присуще только человеку, данные последних десятилетий убедительно доказывают, что его ближайшие родственники, человекообразные обезьяны, обладают достаточным запасом интеллектуальных способностей, чтобы осваивать символы и общаться с их помощью с человеком и собственными сородичами $[10,25,28]$.

Этологи еще в первой половине XX в. пришли к выводу о том, что «обучение животных происходит в основном за счет подражания (имитации), а подражание основано на способности животного уловить и осмыслить значение действий другого индивидуума» $[65$, с. 141]. Ранее полагали, что эта социально-когнитивная форма обучения свойственна только антропоидам. Однако сейчас ее считают наиболее универсальным механизмом обучения, свойственным многим позвоночным животным. При этом имитация трактуется достаточно широко и включает разные варианты обучения: простое привлечение внимание, соревновательное обучение (когда животное, наблюдая за другим животным, побуждается к аналогичным действиям, но стремится добиться этой же цели по-своему), простая имитация (копирование «в один ход»), сложная имитация с последовательностью действий, транспонирование сложных иерархически организованных поведенческих моделей. «Самая простая форма обучения среди животных - привлечение внимания к объекту, а самая сложная - наставничество с активным инструктированием. Между этими крайними формами есть много промежуточных, основанных на сочетании подражательного поведения, реализации врожденной программы и приобретении индивидуального опыта в процессе имитации» [65, с. 142-143].

Особую роль непроизвольная подражательная способность играет и в процессе антропогенеза, в частности, в развитии речевых свойств человека: «...Подражательный рефлекс эксплуатируется почти на всех 
уровнях социальной технологии (от обучения детей до массовых действий и ритуалов, а также в пропаганде и рекламе)» [90, с. 176]. При этом «важно помнить, что приобретенные путем научения реакции не наследуются потомством. Передаются лишь степень пластичности и способность обучаться, которые в свою очередь “заданы” генетическим кодом и программой развития» [71, с. 186].

\section{В чем же все-таки отличие человека?}

Еще во второй половине XIX в. Ж.М. Гюйо, не проводя резкой границы между сознанием человека и животных, с удивительной проницательностью утверждал: «Одна из черт, отличающих человека от животного и цивилизованного человека от дикаря, состоит в том, что интеллект его долее остается способным приобретать новые знания, что он не останавливается в росте и не закрывается над приобретенным знанием...» [16, с. 219].

Современное естествознание подтверждает справедливость этой точки зрения. Самые большие психофизиологические отличия человека от животных отмечаются в ритме, скорости и продолжительности развития мозга, а также в объеме памяти, объеме коммуникативных и инструментально-творческих способностей. Однако эти различия не имеют принципиального характера.

В 1960-х гг. в опытах по совместному воспитанию детей человека и детенышей человекообразных обезьян делались заключения о том, что даже у шимпанзе - обезьян, эволюционно наиболее близких человеку, - с наступлением полового созревания происходит генетически запрограммированное завершение развития мозга, в то время как у человека высшие отделы мозга остаются потенциально не ограниченными в своем развитии [19].

Педагоги-практики отмечают и у подростков в период полового созревания некоторое рассеивание внимания, заторможенность в восприятии и выработке суждений, требующих сосредоточенного абстрактного мышления. Но эти затруднения обычно носят временный, ситуативный характер, так как обусловлены не пределом развития мозга, а эмоциональным напряжением, связанным с возрастными особенностями гормональной регуляции. Воспитание и длительное изучение «говорящих обезьян», особенно за последние два десятилетия, показало, что способности к научению языку и определенным манипуляциям с предметами проявляют и взрослые обезьяны, а у некоторых бонобо речевой опыт накапливается в течение всей жизни. По мнению этологов, интеллектуально-речевая ограниченность «говорящих» бонобо заключалась не в возрастных пределах, а именно в освоении смысла предметов, который был ограничен возможностями их использования, то есть образом жизни [10].

По-видимому, воспитателям «говорящих» обезьян удалось приблизить их к уровню сознания человека лишь в той мере, в какой получилось создать доступные для их понимания условия жизни, подобные образу жизни человека. И несомненно, речевые ограничения в освоении смысла предметов коррелируют с наследственными ограничениями развития мозговых структур.

Вопрос об отличии животных от человека и ограниченной возможности их обучения в какой-то мере может прояснить изучение орудийной деятельности. Как показано в обзоре Ж.И. Резниковой [67], орудийная деятельность встречается в основном у человекообразных обезьян и птиц - соек, вьюрков, галок, ворон, попугаев, грифов и др. Как правило, она требует социального обучения, хотя у разных видов роль такого обучения различна, например:

1) у человекообразных обезьян социальное обучение преобладает;

2) для голубых соек оно не является решающим, хотя и весьма существенно;

3) для вьюрков Дарвина выполняет подчиненную роль;

4) для новокаледонских галок служит лишь дополнением к эффективному и быстрому накоплению индивидуального опыта.

Но в любом случае при формировании орудийного поведения очень важна встреча животного с соответствующими стимулами в критические, наиболее чувствительные для этого периоды онтогенеза: «Во всех случаях, когда в формировании орудийной деятельности участвует в качестве составляющей накопление и совершенствование опыта, можно... говорить о видотипической склонности к образованию специфических ассоциаций» [67, с. 17]. Причем оказалось, что во многих случаях вороны и галки могут быть даже сообразительней обезьян. Ж.И. Резникова отмечает, что обезьянам, овладевающим предметной деятельностью, часто мешают приноровиться к новой ситуации как раз те навыки, которые уже были получены прежде. Они плохо принимают во внимание изменение условий эксперимента, не восприимчивы к деталям, действуют неточно, небрежно, успех чаще бывает случайным. Интересна мысль этолога о том, что здесь происходит «слишком быстрое <a, возможно, и слишком прочное, - И.Л.> образование специфических ассоциаций, <которое > может играть тормозящую роль, превращаясь в груз приобретенных стереотипов и препятствуя инновационным решениям» [67, с. 18$]$.

Для объяснения этого феномена Дуайт Рид в 2008 г. привлекает гипотезу ограниченного рекурсивного мышления: обезьяны, по сравнению с людьми, обладают значительно меньшей кратковременной, или рабочей памятью, что ограничивает их возможности мыслить рекурсивно, то есть использовать в новой ситуации уже имеющийся опыт аналогичных операций [121]. По его мнению, в рабочей памяти обезьян вмещается не более двух-трех концепций, тогда как у человека - до семи.

В 2007 г. американские исследователи Е. Герман, Дж. Колл и соавт. показали, что различие между человеческим и обезьяньим интеллектом обусловлено способностью к социальному общению. Оказалось, что дети в возрасте двух с половиной лет справляются с задачами «социального» характера гораздо лучше обезьян, хотя в решении «физических» задач шимпанзе и орангутаны ничуть не уступают детям $[52,106]$. На основании этих данных была предложена «гипотеза культурного интеллекта», согласно которой выдающиеся интеллектуальные способности человека развились благодаря особо сложной и гибкой социальной организации людей. Причем умственные способности людей в ходе эволюции развивались неравномерно: ранее всего возникли именно 
социально-ориентированные задатки, и лишь затем все остальные способности.

В 2011 г. венгерские нейробиологи К. Хорват, Я. Мартос и соавт. обнаружили, что с общительностью связан и размер самых поздних образований мозга: оказалось, что общительность у обезьян и человека положительно коррелирует с размером лобных и височных долей, размером неокортекса и всего конечного мозга [107]. Эти данные подтвердили, что быстрое увеличение новейших отделов мозга в эволюции гоминид было связано с развитием «социального интеллекта», то есть умственных способностей, направленных на понимание поступков и мотивов соплеменников и эффективное взаимодействие с ними. Таким образом, подчеркивает А. Марков, «сложные социальные отношения были важным стимулом увеличения мозга в эволюции наших предков» [55].

Для когнитивной - как мыслительной, так и орудийной деятельности человека, в отличие от даже самых «умных» животных, характерны значительно меньшее давление стереотипа, значительно более высокая чувствительность восприятия в любых меняющихся ситуациях и способность решать новые задачи, принимая новые решения, на протяжении всей жизни. Ювенильный период жизни человека, как и у животных, - период наибольшей чувствительности восприятия и наиболее эффективного обучения. Бесспорно, что в этот период у всех подвижных организмов включаются и работают с максимальной нагрузкой наследственные программы подражания, причем человеку свойственно «подражать» ничуть не в меньшей, а возможно и в большей степени, чем животным. Однако очевидно и то, что индивидуальный опыт человека не имеет тех наследственных ог- раничений, которые обнаруживаются у животных: однажды полученный опыт не может быть препятствием для приобретения нового опыта; наоборот, он обычно способствует развитию новых знаний и навыков на любых этапах жизненного цикла.

Сравнение животных, стоящих на разных ступенях эволюции, показало, что уровень их социальной организации и когнитивного развития точнее всего отражают не абсолютные, а относительные размеры различных отделов мозга: максимальная в онтогенезе величина отношений массы головного мозга к массе спинного мозга, а также массы коры, в особенности неокортекса - к общей массе головного мозга (табл. 1).

Еще более показательны в отношении высоты организации высшей нервной деятельности человека, по сравнению с животными, величины коэффициентов энцефализации и численности кортикальных нейронов (табл. 2).

Как российские (Н.П. Наумов и Н.Н. Карташов), так и немецкие (Г. Рот и У. Дике) ученые показали, что величина мозга, определяемая по его массе, хотя и может при сравнении различных классов позвоночных или крупных систематических групп млекопитающих косвенно свидетельствовать об общем направлении эволюции на увеличение массы мозга, тем не менее является слишком грубым показателем для оценки когнитивных и, тем более, интеллектуальных различий, поскольку она, прежде всего, зависит от общего размера тела животного. Уровень интеллектуального потенциала животных и человека прямо зависит не столько от размеров мозга, сколько от количества и плотности концентрации нейронов в отдельных участках мозга (так называемое серое вещество), а также от количества связей между ними [123].

Средние показатели эволюционного развития мозга и высшей нервной деятельности у животных различных систематических групп (по данным [60, с. 56, 142, 238])

\begin{tabular}{|c|c|c|c|}
\hline $\begin{array}{c}\text { Классы и группы } \\
\text { позвоночных животных }\end{array}$ & $\begin{array}{c}\text { Процентное } \\
\text { отношение головного } \\
\text { мозга к массе тела }\end{array}$ & $\begin{array}{c}\text { Отношение массы } \\
\text { головного мозга } \\
\text { к массе спинного мозга }\end{array}$ & $\begin{array}{c}\text { Процентное отношение } \\
\text { переднего мозга } \\
\text { к общей массе мозга }\end{array}$ \\
\hline Хрящевые и костные рыбы & $0,02-0,94$ & Меньше 1 & \\
\hline Земноводные & $0,3-0,73$ & & \\
\hline Пресмыкающиеся & $0,01-0,4$ & Меньше или равен 1 & $42-52$ \\
\hline \multicolumn{4}{|l|}{ Птицы } \\
\hline Бескилевые и пингвины & $0,04-0,09$ & & \\
\hline Куриные, гуси & $0,4-0,6$ & 1,5 & \\
\hline Голуби & \multirow{3}{*}{ 1-3 } & 2,5 & \\
\hline Хищные & & & \\
\hline Воробьиные & & & 70 \\
\hline Все летающие & $0,2-8,4$ & $0,5-5$ & $52-62$ \\
\hline \multicolumn{4}{|l|}{ Млекопитающие } \\
\hline Копытные & & 2,5 & \\
\hline Насекомоядные, хищные & & $3-5$ & \\
\hline $\begin{array}{l}\text { Насекомоядные } \\
\text { (крупные и мелкие) }\end{array}$ & $0,6-1,2$ & & \\
\hline $\begin{array}{l}\text { Китообразные } \\
\text { (крупные и мелкие) }\end{array}$ & $0,3-1,7$ & $10-15$ & $76-80$ \\
\hline Приматы & $0,6-1,9$ & & \\
\hline Человек & $1-3$ & 45 & 86 \\
\hline
\end{tabular}


Основные показатели размера и нейронной сложности головного мозга

у некоторых представителей млекопитающих (по [123, p. 251])

\begin{tabular}{|c|c|c|c|}
\hline Млекопитающие & $\begin{array}{c}\text { Macca } \\
\operatorname{м03га~}(г)\end{array}$ & $\begin{array}{c}\text { Коэффициент } \\
\text { эншефализашии * }\end{array}$ & $\begin{array}{c}\text { पисло нейронов в коре головного мозга } \\
\text { (миллионы) }\end{array}$ \\
\hline Киты & $2600-9000$ & 1,8 & 1000 \\
\hline Африканский слон & 4200 & 1,3 & 11000 \\
\hline Человек & $1200-1450$ & $7,4-7,8$ & 11500 \\
\hline Бутылконосый дельфин & 1350 & 5,3 & 5800 \\
\hline Морж & 1130 & 1,2 & \\
\hline Верблюд & 762 & 1,2 & \\
\hline Бык & 490 (до 700) & 0,5 & \\
\hline Лошадь & 510 & 0,9 & 1200 \\
\hline Горилла & $430-570$ & $1,5-1,8$ & 4300 \\
\hline Шимпанзе & $390-430$ & $2,2-2,5$ & 6200 \\
\hline Лев & 260 & 0,6 & \\
\hline Гиббон & $88-105$ & $1,9-2,7$ & \\
\hline Макака Резус & 88 & 2,1 & 480 \\
\hline Белогрудый капуцин & 57 & 4,8 & 610 \\
\hline Собака & 64 & 1,2 & 160 \\
\hline Лиса & 53 & 1,6 & \\
\hline Кошка & 25 & 1,0 & 300 \\
\hline Белка & 7 & 1,1 & \\
\hline Крыса & 2 & 0,4 & 15 \\
\hline Мышь & 0,3 & 0,5 & 4 \\
\hline
\end{tabular}

* Коэффициент энцефализации (индекс энцефализации) - мера относительного размера мозга, определяемая как соотношение между отношением фактической массы мозга к средней массе тела данного вида животного и таким же показателем другого животного, принятым за стандартную единицу. В данной таблице за стандартную единицу принято отношение массы мозга к массе тела у кошки.

\section{4. Сознание как условие социальной коммуникации}

Родовые отношения и культурное воспроизводство лежат в основе всей системы общественных отношений как у человека, так и у высших животных, и целиком определяют образ жизни семьи и сообщества в целом. Специфика нравственных отношений между людьми заключается, главным образом, в исключении физической и психической агрессии и в отказе от нанесения как физического, так и психического вреда. На социальном уровне она выражается в механизмах регуляции повседневных отношений между людьми (в интересах каждого человека и общества в целом), направленных на ограничение насильственного принуждения ради сохранения физического и психического здоровья. При этом происходит мобилизация сознания и воли людей в направлении, необходимом для согласованного индивидуального и общественного развития. Главным результатом нравственной регуляции является ненасильственная сознательная (внушенная, воспитанная или даже, отчасти, навязанная) самоорганизация общества. Аналогичным образом регулируются и социальные отношения высших животных.

Данная регуляция осуществляется с помощью формирования определенных психических впечатлений и переживаний, как подсознательных, так и сознательных, а большей частью смешанных - подсознательных и сознательных одновременно. Эти впечатления могут обеспечиваться как посредством врожденных поведенческих реакций или стратегий, так и с помощью когнитивных функций, которые, как и у животных, связаны с развитием сознания в процессе наполнения его поступающей извне информацией. Нравственные представления человека, так же как и альтруистические наклонности животных, формируются на базе инстинктов и эмоций с обязательным участием умственной деятельности. И те и другие имеют определенные генетические детерминанты. В то же время и те и другие механизмы испытывают обязательное влияние среды, включая сложную социальную коммуникацию. Нет никаких сомнений в том, что человека от животных отличает особо сложная социально-культурная среда и соответствующая языковая - вербальная коммуникация, связанная с уникальными когнитивными способностями, которые проявляются в большом объеме памяти, обилии ассоциаций, сложном абстрактном мышлении и воображении. Им соответствуют и определенные структурные особенности центральной нервной системы: максимальная величина отношений массы головного мозга к массе спинного мозга, массы коры к общей массе головного мозга, а также количество и плотность контактов нейронов коры. Кроме наследственных свойств характера, на проявлении свойств альтруизма и эгоизма человека обязательно сказываются культурные особенности социальной среды, нравственной системы воспитания и идеологии.

Нейропсихологи сегодня обнаруживают, что на уровне функционирования головного мозга человека возникают в той или иной степени осознаваемые, противоположно направленные мотивы $[5,18,73]$. Эмоционально-гормональные отделы лимбической системы (промежуточный мозг и древние отделы коры) формируют, независимо от сознательной де- 
ятельности, импульс индивидуальной потребности «хочу», а когнитивные отделы неокортекса, или новой коры, формируют сознательный импульс «надо» как ограничение импульса «хочу» [72]. Мыслительно-волевой акт - принятие решения и команда к действию - происходят в борьбе этих противоречивых импульсов внутри самого организма и мозга человека: эгоистических (на уровне его эволюционно более древних отделов) и альтруистических, тормозящих эгоистические (на уровне эволюционно самых молодых отделов - мыслительной коры). Принятие решения и соответствующее действие устраняют это внутреннее противоречие, снимают напряжение и возвращают систему мозга к невозбужденному, уравновешенному состоянию.

Американским нейропсихологам М. Конигсу и Д. Трэнэлу удалось показать [111], что у нормальных людей способность давать морально-этические оценки или совершать нравственные поступки зависит не только от рассудка, но и от эмоциональных свойств, в частности таких, как способность к сочувствию или состраданию, за которые отвечают определенные отделы головного мозга. Отсутствие такой способности связано с нарушениями, локализованными в вентромедиальной части префронтального слоя коры (ВМПК). Выяснилось, что не способные к состраданию, жестокосердные люди не испытывают смущения, стыда и чувства вины, хотя на уровне сознания отлично понимают, что хорошо, а что плохо, то есть несмотря на то, что им хорошо известны правила морали и общепринятые нормы поведения. Другие эмоциональные реакции у них выражаются сильнее, чем у обычных людей. Они не могут сдерживать гнев и легко впадают в ярость, что не может не сказываться на принятии нравственных решений.

В аналогичных работах, проведенных ранее на животных и, в частности, в России, на крысах и кошках, были показаны индивидуальные различия не только нейрофизиологических показателей реакций альтруизма, но и способностей к обучению этим реакциям [74].

При этом альтруизм оценивался как способность воспринимать боль других особей с ответной реакцией избегания причинения страдания, то есть как проявление реакции сострадания. Эгоизм, напротив, оценивался по отсутствию этой реакции и по проявлению противоположной реакции - удовольствия. В обзоре П.В. Симонова приводятся данные, свидетельствующие о том, что у крыс, собак, обезьян и людей соотношение особей, чувствительных и нечувствительных к боли партнера, мало различается и составляет примерно 1:2. К сожалению, эти интересные данные не имели единого критерия разграничения свойств чувствительности и нечувствительности, и полученное совпадение частот еще нуждается в методологическом обосновании.

\section{5. Психогенетические исследования}

Практика воспитания издавна показывала, что нравственные свойства обусловлены не только социальными факторами (условиями жизни и характером воспитания), но и биологическими особенностями человека. И хотя для мыслителей естественнонаучного направления, как и большинства философов, было свойственно, прежде всего, обращать внимание на процесс воспитания, идею комплексного влияния поддерживали многие выдающиеся деятели науки.
Русский ученый И.И. Мечников был среди первых, кто еще в начале прошлого века взвешенно и точно высказался о природной сущности альтруизма и эгоизма, о преобладании эгоистов в обществе и о возможности коррекции эгоистического поведения человека с помощью нравственных принципов и необходимости обучения этим принципам [59].

Наибольшие споры всегда вызывал вопрос о соотношении факторов наследственности и воспитания в процессе формирования человеческой личности, которые проявляются в столкновении индивидуальных и общественных интересов [1, с. 127; 2], биологического и социального $[8,45]$, природы и культуры [35], телесной и духовной сущности человека [56].

Основной вывод психологов и философов о неразрывной связи природно-биологических и социально-культурных факторов в жизни человека соответствовал заключениям генетиков о том, что его наследственные возможности могут быть реализованы только под воздействием внешней среды, а влияние внешней среды ограничивается индивидуальными наследственными возможностями $[31,81]$. Пределы модификации психогенетических реакций достаточно широки, причем в зависимости от определенных внешних воздействий могут изменяться и сами генетические ограничения [21, с. 36-37].

Наследственный характер в первую очередь был обнаружен у наиболее устойчивых - морфологических свойств, таких как цвет глаз, цвет и структура волос, рост и различные черты строения лица и тела. Сегодня всем понятно, что внешние признаки рас и национальностей тоже имеют генетическую природу. Очевидна и правота генетических теорий наследования групп и резус-факторов крови, дальтонизма, мигрени, шизофрении, слабоумия, карликовости и т. д. И, хотя давно замечено, что наследственным патологиям (например, карликовости, гигантизму, эпилепсии, базедовой болезни) сопутствуют определенные психологические особенности, наследование некоторых чисто психологических свойств до сих пор многим кажется абсурдом. Трудно представить, что в каждой человеческой личности генетически предопределено, каким скорее всего будет человек: чувствительным и сострадательным или грубым и жестоким. Тем не менее, научная литература сегодня в достаточной мере подтверждает генетическую природу альтруизма и многих других личностных свойств.

Преимущественно путем сравнения близнецов психо- и нейрогенетики установили, что многие личностные качества человека имеют не только социальную, но и генетическую детерминацию. К их числу относятся:

- чувствительность и эмпатия $[12,13,50]$;

- характер активности, темперамент [3, 26];

- интеллект, умственное развитие, гениальность, склонность к наукам [93];

- эгоизм как условие для проявления девиантного и безнравственного поведения, агрессивность и криминальные наклонности, предрасположенность к алкоголизму и наркомании [81];

- некоторые профессиональные и деловые способности (склонность к искусству, религиозной деятельности, бизнесу) $[3,26]$;

- нравственные качества - альтруизм, склонность оказывать помощь [78; 91; 92; 125, p. 827-828, 892]. 
Обычно в работах генетиков подчеркивается ведущее значение генотипа при формировании характера и навыков общения. Однако встречаются и очень яркие примеры существенного влияния среды. У И.И. Канаева описан интересный случай воспитания с младенческого возраста двух сестер (однояйцевых близнецов) в разных по культурному уровню семьях - в городе и на ферме. Первая получила высшее образование и стала учительницей, вторая окончила начальную школу и занималась на ферме домашним хозяйством. Обе вышли замуж и имели детей. Но при сохранении сходства в чертах лица и характера их внешний облик и поведение разительно отличались: первая заботилась о внешности, была миловидна, общительна, любезна, казалась моложе и симпатичней; вторая одевалась небрежно, была мало разговорчива, грубовата, казалась некрасивой и значительно старше [34].

Сегодня результаты применения близнецового метода, который до сих пор играл ведущую роль в изучении альтруизма и эгоизма, нуждаются в дополнительных исследованиях. Кроме моно- и дизиготной близнецовости, были обнаружены промежуточные варианты, появление которых связано с ранним влиянием на монозиготу некоторых особенностей внутриутробной материнской среды [32]. Таким образом, возникает необходимость в уточнении влияния близнецового фактора как «степени близнецовости». К тому же становится все сложнее отделить мутагенные факторы, глубоко меняющие наследственные свойства организма, от факторов, вызывающих ненаследственные - модификационные изменения.

Психогенетики уверены, что ни одна психологическая черта или особенность поведения человека не формируется без участия наследственных факторов [30, с. 381], хотя при этом исследователи по-разному оценивают вклад наследственных факторов в формирование личности. По данным американских ученых, изучавших взрослых близнецов, интеллектуальные способности в основном зависят от генов и лишь на $10-15 \%$ могут изменяться под влиянием внешней среды; проявление же альтруизма, по данным этих исследований, почти в равной степени зависит как от генов, так и от среды [26, с. 445-449].

В других зарубежных и отечественных работах показана наряду с очевидной наследственной предопределенностью значительная степень зависимости, например, интеллектуальных свойств и особенностей характера, от внешних воздействий и, в частности, от организации процесса обучения. У очень маленьких детей в возрасте до полутора лет влияние среды и воспитательных воздействий почти не проявляется в таких поведенческих реакциях, как активность, раздражительность, агрессивность; в то же время такое свойство, как общительность ребенка, во многом зависит от семейной среды [77, с. 45-46].

Установлено, что общее влияние среды воспитания на проявление когнитивных функций (внимательность, память, логичность и др.) является максимальным и достигает $60 \%$ в дошкольном и предподростковом возрасте; в подростковый период оно снижается до 40\%, в юности - до 20-30\% и далее во взрослом состоянии - до 0, хотя индивидуальные средовые различия на протяжении всей жизни могут сохраняться на уровне $20 \%$ [23; 24, с. 186].

Сравнение электроэнцефалографических показателей у детей, подростков и лиц юного или молодого возраста показывает высокий уровень зависимости от генетических факторов (от 50 до 85\%), причем самая высокая корреляция с наследственностью (85\%) проявляется в подростковом возрасте [64, с. 412-415]. Однако «изменение средовых условий, в том числе и социокультурных, может менять структуру дисперсии признака; это особенно справедливо для психологических признаков и прежде всего для тех, которые принято относить к личностным чертам, относящимся, по определению, к наиболее зависящим от социокультурных условий...» [63, с. 248].

По нашим популяционным данным, специфическая эмпатическая, точнее, предэмпатическая, способность к восприятию человеком другого человека («человекочувствительность»), а также степень альтруизма как сострадательность и готовность следовать нравственным нормам, выявленные у школьников и студентов в возрастном периоде от 11 до 22 лет, оказались наибольшими в доподростковом периоде (11-12 лет) и наименьшими - у подростков (13-15 лет); существенное различие этих показателей затрагивало до 50\% учащихся [41, 42].

\section{6. Социобиологическая теория альтруизма}

Первым системным разработчиком социобиологической теории поведения животных и человека, в которой альтруизму и эгоизму отводилась ключевая роль, был Эдвард Уилсон. Работа в этом направлении велась с 30-х гг. ХХ в. Уилсон исходил из того, что любое живое существо (включая человека) находится во власти так называемого «репродуктивного императива», который определенным образом структурирует мотивы поступков и взаимоотношений как между животными, так и между людьми, в результате чего возникает определенная иерархия сообщества. Понятие «адаптивности» Уилсон определял как успех в воспроизводстве генов, то есть как способность оставлять самых сильных в репродуктивном отношении потомков. Все нравственно-культурные ограничения человека нацелены на воспроизводство генов. Кровнородственные связи не только запрещаются культурой, но и вызывают у субъекта эмоционально негативную реакцию. Таким образом, социальные отношения, по Уилсону, имеют столь же культурно-историческую, сколь и эволюционно-генетическую основу, определяющую порядок их развития. Целесообразность социального поведения заключается в стремлении сохранить и упрочить в поколениях свой генофонд, то есть разнообразие и численность генов популяции [129]. Популяционноадаптивный смысл, несущий выгоды сообществу в целом, имеют и свойства альтруизма [130].

В 1950-х гг. Э. Уилсон использует и развивает концепции У. Гамильтона о совокупной приспособленности и родственном отборе альтруизма: повышая эволюционное «благополучие» родственника (даже в ущерб собственному благополучию), альтруист способствует сохранению и выживанию своего генотипа. Ведь каждый отдельный организм - в своем роде «колония генов», которая в целях выживания «кооперируется» с генами других организмов - биологических родственников, у которых часть генов является общей для всех. Так альтруизм людей проявляется как биологически целесообразное поведение, прежде всего, по отношению к близким родственникам. Но 
аналогичное поведение целесообразно и в отношении дальних родственников, то есть всех представителей собственного вида, поэтому оно может сохраняться и как механизм выживания вида. Таким образом, альтруистическое поведение, подвергая риску генетический материал индивида и повышая вероятность выживания генетически родственных социальных партнеров, способствует сохранению общего генофонда [103, 130, p. 35].

«Первичным социумом», имеющим биологическую природу, Уилсон считает связь между родителем и ребенком, которая играет роль «устройства, увековечивающего гены». Воспитание детей носит генетически-адаптивный характер и служит собственному «генетическому интересу» родителей. Репродуктивный императив настойчиво требует воспроизводить свои гены каким угодно способом: то ли во множестве потомков, оставляя их на произвол судьбы, то ли в их небольшом количестве, но обеспечивая наилучшие возможности для последующего воспроизводства. При этом родительская привязанность обратно пропорциональна уровню рождаемости. Каждое поколение людей является потомками индивидов, рассматривающих воспроизводство генов как исключительно положительную ценность. Отсюда Уилсон выводит устойчивость нравственных норм родительского поведения, направленных в конечном счете на воспитание репродуктивной установки у детей. Причины конфликтов между родителями Уилсон видит в том, что каждый пытается заставить другого тратить как можно больше усилий на воспитание детей - общих «носителей генов» [131, p. LVII].

Совместно с Ламсденом Уилсон создает концепцию геннокультурной коэволюции, согласно которой культура и биологические свойства подвержены взаимному влиянию, в результате чего «человеческие гены, память и культура обеспечивают коэволюционный процесс» [115]. Культура, как правило, не отрицает, а поддерживает эволюционно-генетический процесс, поскольку помогает обеспечивать биологическую адаптацию и воспроизводство человека. Если же требования социально-биологической и социально-культурной жизни значительно расходятся, шансы на выживание данного сообщества существенно снижаются. Индивиды, наиболее приспособленные для выживания в современной им культуре, передают больше соответствующих генов своим будущим поколениям, а эти гены предопределяют сформированный предками психический строй человека, от которого зависит и культура. Таким образом, культура влияет на отбор биологического материала и сама же подвержена его влиянию. По мнению Уилсона, именно альтруистический поведенческий комплекс лежит в основании типовых (традиционных, культурных) социальных связей, так как он формирует ключевые, биологически детерминированные формы социального поведения у всех видов организмов, включая человека [129, p. 31; 132].

Сегодня происхождение и социальная роль альтруистического поведения по-прежнему являются центральной теоретической проблемой социобиологии.

В нашей стране основной вклад в развитие теории социобиологической природы альтруизма внес В.П. Эфроимсон, который под названиями «совесть», «альтруизм» понимал «всю ту группу эмоций, кото- рая побуждает человека совершать поступки, лично ему непосредственно невыгодные и даже опасные, но приносящие пользу другим людям» [91, с. 199].

Альтруизм, по Эфроимсону, - свойство человеческого характера, которое проявляется у разных людей по-разному, в зависимости от их генетических задатков и условий воспитания. В нем он видел источник всех нравственных свойств человека: порядочности, честности, доброжелательности, чувств уважения, дружбы, любви, совести и долга, самоотверженности, заботы о благополучии других, в особенности детей и стариков, стремления к истине и справедливости. По мнению Эфроимсона, наследственное свойство альтруизма служит основанием для возникновения в обществе «комплекса идей гуманизма», морали (этики), в частности, сексуальной этики, науки и искусства. Решающим условием для возникновения этого культурного комплекса он считал биологический процесс естественного отбора и эволюции социальных отношений, закрепленных в генах. Особенностью философской позиции Эфроимсона было то, что он, с одной стороны, признавал высокую степень альтруизма лишь за отдельными личностями, которых меньшинство, а с другой - полагал, что к некоторой, наследственно закрепленной, обязательной для общества степени альтруизма способно большинство людей. Он писал: «Чувство долга, доминирующее в поведении неизворотливого большинства, порождено не кантовскими “звездами на небе" и “божественным законом в сердце", а отработанным за десятки тысяч поколений эволюции комплексом психических и поведенческих реакций, столь же необходимых человечеству, как речь, как умение пользоваться орудиями» [92, с. 54]. Происхождение альтруизма Эфроимсон связывал с механизмами полового влечения, особенно заботы о потомстве, которые наследственно закреплены отбором как у человека, так и у животных. В современных гипотезах о происхождении альтруизма не исключается возможность возникновения индивидуальных генетических различий в результате мутаций, которые затем могли закрепиться в определенном механизме комбинативной генотипической изменчивости [33, 36]. Идеи Эфроимсона о генетической основе альтруизма, которая имеет общее эволюционное происхождение и свойственна как человеку, так и животным, сегодня успешно подтверждаются.

Израильскими учеными [110] получены данные о том, что «гены альтруизма», которые у низших млекопитающих снижают уровень агрессии и способствуют социальному объединению, аналогично проявляют себя и в человеческом поведении. В экономической игре они содействуют проявлению доверия к партнерам и принятию не только более экономически успешных, но и более нравственных решений.

В обзоре Б.Б. Фукса показано, что именно варианты этих регуляторных генов, определяющие уровень нейрогормональной активности мозга с участием вазопрессина и окситоцина, ответственны за социальное, в частности, альтруистическое или эгоистическое поведение как у животных, так и у человека [87]. Различные варианты генетической регуляции синтеза и восприятия нейронами мозга окситоцина и вазопрессина определяют у человека уровень доброты и склонности доверять другим людям [109]. 
В 2011 г. немецкие исследователи показали [122], что альтруистическое поведение, наследственно обусловленное активностью окситоцина и вазопрессина, определяется зависимостью функций этих нейропептидов от катехол-О-метилтрансферазы (КОМТ) - фермента, играющего важную роль в инактивации нейромедиаторов дофамина, адреналина и норадреналина. У тех участников исследования, которые проявили склонность к альтруизму, обнаружились иные варианты полиморфизмов гена КОМТ, чем у тех, кто был более склонен к эгоизму. В 2013 г. канадские исследователи [126] подтвердили, что в основе проявления склонности к альтруизму или эгоизму у человека и животных лежит полиморфизм в системе наследственной регуляции активности окситоцина. Они предположили, что именно комбинации аллелей, влияющих на функции окситоцина, определили эволюцию фенотипического разнообразия поведения, включая проявления альтруизма и эгоизма, у всех социальных животных.

В США Ф. Уарнекен и М. Томазелло установили, что альтруизм как реакция бескорыстной помощи может проявляться уже у полуторагодовалых детей [128]. Детеныши обезьян тоже обнаруживают, хотя и гораздо реже, простые альтруистические реакции. Результаты проведенных исследований свидетельствуют о том, что все высшие приматы имеют врожденные альтруистические реакции, но у человека они значительно сложнее и выражены гораздо сильней. Кроме того, было показано, что взаимопомощь взрослых шимпанзе может проявляться на очень высоком уровне: например, обезьяна может подобрать из связки ключей именно тот, который нужен, чтобы открыть дверцу клетки с сородичем [119]. Правда, исследователи подчеркивают, что такие поступки имеют небескорыстный мотив, и называют их именно взаимопомощью или взаимным (реципрокным) альтруизмом.

\section{7. Альтруизм - социально-} эволюционный противовес эгоизма

Все меньше современные исследователи уделяют внимание чувственной или эмоциональной составляющей альтруистического поведения, хотя во многих работах на животных альтруизм в их поведении характеризуется именно как способность ощущать страдание сородича, то есть как сочувствие, сострадание [78]. О том, что животные способны страдать и вообще эмоционально переживать свое состояние неблагополучия (боль, голод, одиночество, угрозу нападения), писал еще Чарльз Дарвин [17].

Сегодня многие этологи полагают, что высшим животным даже свойственно осознанное отношение к собственной персоне (самоидентификация) [49, c. 478-479] и состоянию своего удовольствия или неудовольствия, то есть эмоции животных - это вполне осознанные выражения их состояния удовлетворенности или неудовлетворенности [49, с. 476-483].

Эмоциональные проявления страдания можно рассматривать и как специфические поведенческие стратегии, которые адаптивно нацелены на то, чтобы вызывать сострадание и помощь [97, p. 420]. И в этом, с точки зрения Мэриэн Докинс, не существует принципиальной разницы между страданиями животных и человека $[98,99]$.

Однако у животных, как, впрочем, и у человека, часто возникают отнюдь не сострадательные, а, ско- peе, жестокие реакции на страдание ближнего. В этом плане весьма показательны наблюдения В.Р. Дольника: «У макак есть одна гнусная инстинктивная программа (встречающаяся и у некоторых других стайных животных, например, у собак). Стоит доминанту начать наказывать одного из подчиненных, как другие спешат ему помочь: кричат, кидают в наказываемого калом, норовят ткнуть чем-нибудь... Этологи разобрались, как возникает такое поведение. Это переадресованная агрессия, накопившаяся в страхе перед доминантом. По обычному иерархическому принципу она переносится на того, кто слабее... Этот простой механизм позволяет доминанту без особого риска для себя подавлять нижестоящих» [22]. Хотя, на наш взгляд, для объяснения поведения макак вовсе не обязательно прибегать к понятию «переадресованной агрессии» (ведь подчиненные макаки могут быть в принципе неагрессивны). Вероятнее всего, причина «гнусного» поведения в том, что процедура наказания «собрата» вызывает у субординантов острый приступ страха и побуждает демонстрировать иерарху свою лояльность: действуя заодно с ним и подражая ему. Аналогичные, вызванные страхом реакции, противоположные состраданию, характеризующие ярко выраженный как индивидуальный, так и коллективный эгоизм, встречаются и среди людей.

Одним из первых крайние формы эгоизма как врожденную склонность к преступлениям подробно изучал Чезаре Ломброзо. Его выводы о преступниках таковы: «...Можно проследить, как они быстро двигаются к апогею порока: начиная с любострастия, лености, эгоизма, они теряют уважение ко всему, освобождаются от всякой обязанности, отбрасывают всякое верование и вполне отдаются своим страстям [46, с. 215]. ...Рассуждения преступников... очень поверхностны [46, с. 214]. ...Врожденные преступники не отличаются правдивостью [46, с. 221]. ...Прирожденный преступник равнодушен, безучастен к страданиям других, еще равнодушнее к своим собственным... часто даже весел перед казнью» [46, с. 310].

Совокупность неэтических или антигуманных свойств человека, то есть эгоизм, который проявляется в жестокости, собственнических или хищнических инстинктах и эмоциях, в жадности, похотливости, лживости, агрессивности, демонстративности, навязчивости, проявлениях коварства и предательства, стремлении к господству и властолюбии, В.П. Эфроимсон рассматривал как противоположность альтруизма [91]. Он полагал, что для эгоизма, так же как и для альтруизма, существует некий механизм наследственной детерминации. В своих выводах он опирался на имеющиеся в научной литературе данные по изучению особенностей жизни, интеллекта и психики у однояйцевых и разнояйцевых близнецов, генетически больных людей и, в частности, преступников с психическими заболеваниями и аномалиями хромосомного аппарата, а также на истории психических расстройств в семьях выдающихся людей с хорошо изученной генеалогией. На основании этого он заключил, что ярко выраженные признаки как альтруизма, так и эгоизма в нормальной популяции встречаются нечасто и закономерности их наследования еще далеко не ясны.

Внимание исследователей обычно привлекают социально опасные проявления эгоизма - агрессивное и криминальное поведение. Эфроимсон также рас- 
сматривал лишь резко выраженные формы эгоизма и подчеркивал их антиобщественное значение. Но более детальное изучение проявлений эгоизма и альтруизма у животных и человека $[48,79,112]$ показывает, что роль эгоизма отнюдь не сводится только к негативным тенденциям. Эгоизм проявляется у человека, как и у животных, в любых индивидуалистических реакциях, которые либо напрямую служат интересам собственного выживания, либо входят в поведенческий комплекс, дающий в целом преимущества в борьбе за существование. Соответствующий норме эгоизм проявляется не только и не столько как опасные для окружающих жестокость, агрессивность, грубость, подлость или коварство, но и через позитивные волевые свойства: храбрость, силу, ловкость, скорость реакции, целеустремленность, честолюбие, высокую половую активность, настойчивость, память, смекалку и сообразительность, максимальное проявление творческих способностей, а также - через терпение, выдержку, хитрость, подозрительность, осторожность и другие качества, направленные на достижение собственного жизненного успеха. Таким образом, эгоизм является полезным свойством и обнаруживается как основная наследственная тенденция в существовании и эволюции вида, и это справедливо как для животных, так и для человека [20].

Этологами установлено, что у животных многих видов (как правило, среди птиц и млекопитающих) общественные отношения формируются в процессе онтогенеза при наличии по крайней мере трех основных условий, сдерживающих врожденный эгоистический антагонизм и агрессию [4, с. $120 ; 27 ; 65 ; 67]$ :

1) врожденные комплексы поведения, связанные с формированием семьи и заботой о потомстве;

2) врожденные механизмы, позволяющие устанавливать контакты с особями своего вида при помощи определенных сигналов;

3) определенный чувствительный период в начале онтогенеза, когда в сознании детей происходит «запечатление» вида родителей, которое впоследствии будет определять характер общественных взаимодействий взрослых животных (импринтинг).

Но как ни велико значение врожденных общественных инстинктов и импринтинга для установления внутривидовых контактов между животными, образование стабильных общественных группировок, по мнению этологов, невозможно без эгоистических проявлений внутривидовой агрессии, которая оказывает разностороннее влияние на жизнь сообщества. С одной стороны, она обеспечивает конкуренцию и выживание наиболее приспособленных особей, поддерживая таким образом жизнеспособность популяций, с другой - способствует изоляции отдельных групп животных в пределах одной популяции и препятствует перемешиванию различных стай животных одного вида при их встрече друг с другом. В частности, она препятствует проникновению в сообщество чужаков и ограничивает число производителей путем изгнания лишних самцов. При этом создается резерв мигрирующих особей, за счет которых в случае необходимости пополняется недостаток производителей. У одиночных животных агрессия и яркая окраска служат для отпугивания друг друга, что способствует их распространению и занятию максимального количества экологических ниш. Наконец, эгоистическая агрессия поддерживает структуру индивидуализированных сообществ, их иерархическую организацию. При всем разнообразии социальных отношений в иерархии общим правилом является поддержание ее структуры путем постоянных столкновений - драк или угрожающих демонстраций. Таким образом, агрессия - это, как правило, внешнее проявление внутреннего общебиологического свойства эгоизма, которое лежит в основе борьбы за существование организмов и имеет необходимое адаптивное значение.

Правда, у большинства эволюционно «продвинутых» видов животных ожесточенность этой борьбы снижается за счет ритуализации, то есть замены нападения демонстрацией силы и угроз, которая существенно снижает уровень опасности для лояльных членов сообщества, особенно для детенышей и молодняка. И чем сложнее социальная организация вида, тем сильнее проявляются, помимо эгоистических, и другие формы поведения, которые условно можно разделить на: 1) коллективно-эгоистические или проальтруистические (забота о новорожденных, потомстве разного возраста, других членах семьи; взаимовыгодное партнерство, взаимопомощь); 2) индивидуально-альтруистические (самоотверженная забота о потомстве и половом партнере, защита детенышей и других членов семьи с риском для здоровья и собственной жизни, реакции сострадания).

При этом не следует альтруизм, в противоположность эгоизму, рассматривать как пассивность. Те же самые формы поведения, которые свойственны «нормальному» эгоизму, становятся проявлениями и альтруизма - с той лишь разницей, что они направлены не на собственное выживание, а на выживание коллектива. Хотя эти формы поведения ограничивают проявления эгоизма, они так же необходимы для выживания вида, как и эгоизм. При сравнении особенностей поведения животных разных типов эгоистические реакции легко обнаружить на всех уровнях биологической организации (как в индивидуальной, так и групповой жизни). Крайние проявления эгоизма среди позвоночных (полное отсутствие заботы о потомстве и даже родительский каннибализм) характерны для низшего класса - рыб. Проявления альтруизма и сложных поведенческих комплексов заботы о младшем поколении чаще встречаются у более высоко организованных животных с более сложными общественными отношениями - среди птиц и млекопитающих.

Если реакции эгоизма сконцентрированы на себе и, большей частью, происходят автоматически, без участия сознания, то реакции альтруизма и у животных, и у человека, преимущественно, требуют работы мышления, они связаны со способностью представить себя на месте другого, чтобы стало возможным проявление сочувствия и сострадания. Хотя, как уже говорилось, принципиально мышление человека не отличается от мышления животных, его мозг обладает гораздо большей памятью и гораздо более пластичен, особенно в восприятии многообразия и сложности социальных отношений, как и всего комплекса условий, связанных с человеческим образом жизни.

Большое влияние на социальную структуру сообщества, например, у стадно-гаремных млекопитающих, оказывает пониженный уровень агрессив- 
ности самок при сохранении относительно высокой агрессивности самцов. Однако родительские связи и забота о потомстве в гаремном стаде обычно проявляются слабей, чем в моногамной парной или парно-стайной и даже одиночной семье, когда агрессивность самок не уступает агрессивности самцов, а забота о «своих» сочетается с высокой агрессивностью к «чужим». При этом даже сам альтруизм может проявляться в форме агрессии. Как это ни парадоксально, самый яркий альтруизм, как и самый высокий уровень заботы о потомстве, проявляется у парных или парно-стайных хищных млекопитающих и птиц. К. Лоренц подчеркивал: «Личные узы, персональную дружбу мы находим только у животных с высокоразвитой внутривидовой агрессией, причем эти узы тем прочнее, чем агрессивнее соответствующий вид» [48, с. 276].

Как уже отмечалось, важную роль в регуляции социального поведения у животных и человека играет гормон окситоцин. Этот нейропептид, который вырабатывается гипоталамусом, транспортируется в заднюю долю гипофиза, где депонируется и выделяется под воздействием внутренних или внешних факторов для активации различных мозговых центров. Израильские нейропсихологи установили, что под действием окситоцина люди становятся более доверчивыми, более склонны проявлять отзывчивость и доброту [109]. Вместе с тем, эксперименты голландских исследователей [100] показали, что окситоцин способствует проявлению альтруизма не всегда, а лишь когда «альтруист» находится среди своих. Стимулируя стремление защищать людей своего круга, он усиливает враждебность по отношению к чужим, которая может проявляться как коллективный эгоизм в актах прямой агрессии и нанесении «упреждающих ударов». А. Марков подчеркивает, что наследственный механизм биохимической окситоциновой регуляции помогает понять, каким образом у людей с древнейших времен сформировался парохиальный альтруизм, направленный только на «своих» [54], который несомненно предшествовал универсальному альтруизму.

Очевидно, на способность к альтруизму влияет не снижение агрессивности вообще, а снижение агрессивности именно внутрисемейных отношений. Благодаря спаянности семьи трудности выживания преодолеваются за счет усложнения связи организмов со средой и, в частности, их социальной организации.

Половые отношения, как древнейший атрибут жизни, возникают в эволюции задолго до формирования устойчивого комплекса заботы о потомстве. Поэтому у большинства животных половое влечение и процессы спаривания не сопровождаются заботой партнеров друг о друге и, тем более, не связаны с проявлениями альтруизма. Анализ этологической литературы показывает, что возникновение альтруизма в результате снижения уровня внутрисемейной агрессивности связано, в первую очередь, с заботой о потомстве [9, 62, 120]. Трогательные примеры самоотверженного ухаживания, супружеской верности и заботы у животных, вероятнее всего, как и высшие формы репродуктивного поведения, возникают в результате общего усложнения биосоциальной организации вида вместе с усилением привязанности к потомству, усложнением заботы о нем и появлением стратегии альтруизма.
Именно заботу о потомстве следует рассматривать в качестве исходного поведенческого комплекса, на базе которого мог появиться и эволюционировать альтруизм.

Максимальная эффективность и согласованность действий между особями становится возможной в моногамно-парной или парно-стайной семье при обязательном общем повышении когнитивной организации вида. И хотя вопрос об эволюции брачных отношений человека до настоящего времени является дискуссионным, не вызывает сомнений, что надежность и взаимность чувств в моногамной семье создают наиболее прогрессивную форму брака, которая обеспечивает наивысшее социально-когнитивное качество потомства. С этой точки зрения, моногамия может рассматриваться как ключевой фактор в ранней эволюции гоминид, позволивший сформироваться в дальнейшем этносам с наиболее высокой культурой социальных отношений $[113,114]$.

Под давлением жесткого естественного отбора животные приобретают оптимальное для выживания данного организма, его семейства и вида соотношение эгоистических и альтруистических свойств. Но при этом обнаруживаются существенные индивидуальные различия: одни особи более склонны к эгоистическим реакциям, другие - к альтруистическим $[14,15,78]$. В результате в сообществе животных формируются три основных типа отношений [42].

1. Эгоистичность каждой особи (подавление конкурентов, индивидуальная агрессия) обеспечивает ей успех в индивидуальной борьбе за существование (выживание вида за счет выживания индивида).

2. Коллективная эгоистичность или проальтруистичность у всех особей в семье (забота, взаимопомощь, коллективная агрессия) поддерживает, закрепляет и сохраняет данную структуру семьи («взаимовыживание», выживание вида за счет выживания семьи).

3. Альтруистичность некоторых отдельных особей (готовность к состраданию и самоотверженной помощи) помогает выжить в коллективной борьбе за существование семье, популяции и виду в целом (коллективное выживание, выживание вида и семьи за счет жертвенного поведения и даже гибели отдельных особей).

В популяции человека действуют аналогичные механизмы. Эгоизм необходим для человеческого общества как биологическая основа борьбы за индивидуальное существование и выживание отдельных особей, наиболее приспособленных к данным условиям существования (индивидуальный естественный отбор). Альтруизм является необходимым условием для более успешного выживания потомства и, в конечном итоге, для всей человеческой популяции в целом (популяционный отбор). Уилсон подчеркивал, что «механизмы, которые регулируют частоту распространения альтруистического гена, должны лежать вне рамок образования групп» $[130$, p. 35]. Специалисты в области медицинской биологии также полагают, что у человека, как и у животных, «эволюция столь важных форм поведения, как сотрудничество и индивидуальный альтруизм, могла происходить на основе внутрипопуляционных разграничений на группы, закономерно отличающиеся степенью генетического родства» [6, с. 289]. 
Резонно полагать, что эгоист, как и всякая дикая форма, является носителем доминантных генов, обеспечивающих стабилизирующий отбор наиболее конкурентоспособных и жизнеспособных особей в популяции [41]. Стремлением сохранить себя эгоист способствует сохранению устойчивой, уже сложившейся структуры популяции и обеспечивает базу естественного отбора, закрепляющего основные свойства вида. Альтруист же, скорее всего, является носителем рецессивных генов, которые по отношению к генофонду эгоизма, вероятно, появляются позднее как специфические мутации, которые хотя и понижают жизнеспособность носителя, но зато способствуют выживанию семьи, популяции, вида.

Фромм рассматривает как производные эгоизма жадность, зависть, нарциссизм и даже «ненависть к жизни», которые, по его мнению, лежат в основе самых тяжелых патологических реакций агрессии и садизма [84]. Специализируясь на изучении патологических состояний психики, он не находит для них общебиологической предпосылки и необоснованно критикует Лоренца, который считает, что агрессия - это лишь внешнее проявление внутреннего общебиологического свойства эгоизма, который лежит в основе борьбы за существование и является основным внутренним фактором выживания [48]. Но Фромм правильно подмечает, что крайне негативные психологические свойства проявляют не все, а лишь те, кто «наделен вполне определенными чертами характера», то есть имеет для этого особые врожденные генетические задатки.

Эгоистичность всегда способствует обострению внутривидовой и внутрипопуляционной борьбы. У животных ее интенсивность жестко регулируется естественным отбором и ограничивается наследственно закрепленными семейными отношениями. У человека же, в своей индивидуальной жизни гораздо более защищенного гораздо более сложно организованными социальными отношениями, давление индивидуального отбора сказывается гораздо слабее. Возможно, поэтому человеческий организм в индивидуальном проявлении своих эгоистических и альтруистических свойств не столь надежно биологически уравновешен, как организм животного. Гетерогенность популяции человека в отношении свойств альтруизма-эгоизма, приводящая к сосуществованию различных генотипов людей, в разной степени проявляющих эти свойства по фенотипу, возможно, является главным фактором биосоциальной регуляции. Такая регуляция повышает шансы выживания для популяции в целом, обеспечивая, с одной стороны, разнообразие индивидуальных форм (в соответствии с возможным разнообразием условий жизни) на необходимом для естественного отбора уровне, с другой - смягчает жестокость конкурентной борьбы за счет более сложного спектра социальных отношений, когда крайние проявления эгоизма одних людей уравновешиваются за счет альтруизма других.

Хотя у человека общественные отношения менее жестко, чем у животных, регулируются врожденными инстинктами и в большей степени зависят от разумной деятельности, наследственная эгоистическая агрессия и в человеческом обществе играет существенную роль. Кроме выполнения главной задачи - выживания индивида, она поддерживает определенную иерархическую структуру общества и обеспечивает, в частности, функционирование государственного аппарата как механизма общественного внушения и принуждения. Она же становится источником массовых бедствий в результате жестокой политической борьбы, репрессий, революций и войн. При общей пользе эгоизма его крайние проявления могут сказываться негативно как на судьбах отдельных людей, так на исторических судьбах народов [84]. Большую опасность в современности представляет крайний эгоизм, противостоящий интересам как отдельных людей, так и общества в целом - не только на индивидуальном, но и корпоративном уровне (криминальный, политический и экономический терроризм). Но организованная на государственном уровне правовая и силовая защита территории и проживающего на ней народа от посягательств криминала или других народов и государств является главным условием выживания данного народа и сохранения его культурной идентичности.

Современное естествознание, существенно раздвинувшее свои границы за счет новейших достижений биологии, дает возможность не только в сфере производственных технологий, но и в сфере социальной политики использовать более точные данные и получать наиболее точные оценки и прогнозы. Как подчеркивает Александр Марков, «для понимания политического поведения людей совершенно недостаточно учитывать только социологические данные. Политологам пора объединить свои усилия со специалистами по генетике поведения, нейробиологами и эволюционными психологами» [53].

\section{Заключение.}

\section{Что же такое альтруизм и эгоизм?}

Прежде всего, это ситуативно проявляющийся характер суждений и поступков человека, противоположных относительно индивидуальных или общественных интересов.

Эгоизм - суждения и поступки, которые индивид совершает исключительно в собственных интересах, невзирая на интересы и мнения других. Альтруизм суждения и поступки, которые индивид совершает, прежде всего, в интересах другого лица, коллектива или общества в целом - то есть на пользу другим и, нередко, во вред себе. Хорошо известно, что практически каждый человек способен и к эгоизму, и к альтруизму, и характер поступка в основном зависит от ситуации. При этом большое значение имеет внутреннее состояние человека, которое также ситуативно. Однако есть и более постоянные тенденции поведения, зависящие от общего уровня культуры, обученности людей нормам поведения и привычки следовать им, доводящей эти формы поведения до автоматизма, а также от врожденных особенностей психики.

С социобиологической точки зрения, эгоизм - это такие выработанные в процессе эволюции и закрепленные в генах формы активности индивида (эволюционно-стабильные поведенческие стратегии), которые повышают шансы его индивидуального выживания относительно других представителей данного вида или среди существ живой природы в целом. Эгоизм связан с удовлетворением необходимых биологических потребностей и является преобладающей тенденцией индивидуального поведения, поскольку обеспечивает успех в конкурентных 
отношениях и выживание наиболее жизнеспособных индивидов, то есть способствует сохранению наиболее живучих генов из генофонда популяции. У людей, как и у животных, это самое древнее, биологическое свойство, которое проявляется как основное свойство жизни в борьбе за существование: прежде всего, в конкурентной борьбе за полового партнера и потомство, а также за жизненно важные средства к существованию - территорию, жилище, пищевые и иные ресурсы. Он может проявляться как в формах крайне агрессивных и опасных для других (например, захват, насильственное принуждение, подавление, изгнание, нанесение физического вреда, уничтожение), так и в более нейтральных формах поведения (например, насмешливые и язвительные замечания, демонстрация каких-либо преимуществ, позы и гримасы пренебрежения или угрозы, обозначение границ своей территории и т. п.).

Альтруизм - напротив, такие выработанные в процессе эволюции и закрепленные в генах формы активности индивида (или эволюционно-стабильные по- веденческие стратегии), которые повышают шансы выживания других представителей вида и понижают шансы его собственного выживания. Альтруизм тоже имеет адаптивное значение, поскольку способствует сохранению генофонда и социальной структуры социума в целом. Он коренится в родительской любви и заботе о потомстве и возникает в эволюции как ограничение проявлений крайних форм эгоизма внутри семьи, внутрисемейной агрессии. Внешне реакции альтруизма могут проявляться в точности так же, как и реакции эгоизма, но их направленность иная - в интересах социума, а не самого индивида. Именно поэтому человеческий социум оценивает альтруизм всегда позитивно и закладывает принципы альтруизма в нормы морали, которые поддерживаются культурой. Общественная мораль, в сущности, всегда альтруистична, поскольку главная задача любой морали - разумное ограничение индивидуального эгоизма людей. Кроме того, она психологически опирается на альтруизм как на естественную способность человека к состраданию и самопожертвованию.

\section{Литература}

\section{Список русскоязычной литературы}

1. Абульханова КА. О субъекте психической деятельности. М.: Наука; 1973.

2. Абульханова-Славская КА. Соотношение индивидуального и общественного как методологический принцип психологии личности. В кн.: Теоретические проблемы психологии личности. М.: Наука; 1974, с. 34-82.

3. Александров АА. Психогенетика. СПб.: Питер; 2006.

4. Бляхер ЛЯ. История биологии (с начала XX века до наших дней). М.: Наука; 1975.

5. Богданов ИВ, Лазарев СВ, Ануфриенко СС, Чмыхова ЕВ, Усольцева ИВ, Калинина НВ. Психология и педагогика. Глава 5: Структура психики. Раздел 5.2: Когнитивные теории мотивации. Интернет-библиотека Гумер. URL: http://www.kspu.ru/ffec/psych/ps5.html

6. Богоявленский ЮК, Улиссова ТН, Яровая ИМ, Ярыгин ВН. Биология. М.: Медицина; 1985.

7. Бодрийар Ж. Забыть Фуко. СПб.: Владимир Даль; 2000, с. 5-37.

8. Брушлинский АБ. О соотношении биологического и социального в развитии личности. В кн.: Теоретические проблемы психологии личности. М.: Наука; 1974, с. 83-121.

9. Бутовская МЛ. Тайны пола. Мужчина и женщина в зеркале эволюции. Фрязино: Век2; 2004.

10. Бутовская МЛ. Человек и человекообразные обезьяны: языковые способности и возможности диалога. Зоологический журнал. 2005;84(1):149-57.

11. Бутовская МЛ. Эволюционные основы агрессии и примирения у человека. URL: http:// www.polit.ru/lectures/2009/02/12/butov.html
12. Гаврилова ТП. Экспериментальное изучение эмпатии у детей младшего и среднего школьного возраста. Вопросы психологии. 1974;(5):107-14.

13. Гаврилова ТП. Понятие эмпатии в зарубежной психологии. Вопросы психологии. 1975;(2):145-58.

14. Герлинская ЛА. Изменчивость животных по стрессовым реакциям. Автореф. дис. ... канд. биол. наук. Новосибирск; 1987.

15. Герлинская ЛА, Мошкин МП, Евсиков ВИ. Методические подходы к оценке стрессированности диких млекопитающих. Экология. 1993;(6):97-100.

16. Гюйо ЖМ. Воспитание и наследственность. Социологическое исследование (1889). М.: ЛКИ; 2007.

17. Дарвин Ч. О выражении эмоций у человека и животных. СПб.: Питер; 2001, с. 8-43.

18. Дельгадо Х. Мозг и сознание. М.: Мир; 1971.

19. Дембовский Я. Психология обезьян. М.: Наука; 1963.

20. Докинс РК. Эгоистичный ген. М.: Мир; 1993.

21. Докинс РК. Расширенный фенотип. Длинная рука гена. М.: Астрель; 2010.

22. Дольник ВР. Этологические экскурсии по запретным садам гуманитариев. Природа. 1993;(1):72-85.

23. Егорова МС, Зырянова НМ, Паршикова ОВ, Пьянкова СД, Черткова ЮД. Генотип, среда, развитие. М.: Объединенное гуманитарное изд-во; 2004.

24. Егорова МС. Исследование развития в психогенетике. В кн.: Психогенетика. М.: Академия; 2006, с. 181-97. 
25. Ефремов К, Ефремова Н. Эти бонобо знают английский получше нас! URL: http:/ ethology.ru/library/?id=109

26. Жимулев ИФ. Общая и молекулярная генетика. Новосибирск: Сибирское университетское изд-во; 2006.

27. Зорина ЗА, Полетаева ИИ, Резникова ЖИ. Основы этологии и генетики поведения. М.: Изд-во МГУ; Высшая школа; 2002, с. 122-51.

28. Зорина ЗА, Полетаева ИИ. Элементарное мышление животных. М.: Аспект Пресс; 2002.

29. Зорина ЗА, Смирнова АА. О чем рассказали «говорящие» обезьяны. М.: Языки славянских культур; 2006.

30. Ивз Л, Хит Э, Мартин Н, Майес Х, Нил М, Кендлер К, Кирк К, Кори Л. Сравнение биологического и культурного наследования личности и социальных установок. В кн.: Психогенетика. М.: Академия; 2006, с. 338-81.

31. Инге-Вечтомов СГ. Генетика с основами селекции. М.: Высшая школа; 1989.

32. Исакова ГК. Три типа близнецовости в эмбриогенезе у норки (Mustela vison). Генетика. 2007;43(2):280-3.

33. Чайлахяна ЛМ. Истоки альтруизма. Человек. 1995;(5-6):10-9. URL: http://mydocx.ru/ $5-55730$. html

34. Канаев ИИ. Близнецы и генетика. Л.: Наука; 1968.

35. Кемеров ВЕ. Проблема личности: Методология исследования и жизненный смысл. М.: Политиздат; 1977, с.181-92.

36. Корочкин ЛИ. Онтогенез, эволюция и гены. Природа. 2002;(7):10-9.

37. Косоногов В. Зеркальные нейроны: краткий научный обзор. Ростов н/Д: Антей; 2009.

38. Кропоткин ПА. Взаимопомощь как фактор эволюции. М.: Самообразование; 2007.

39. Кропоткин ПА. Этика. М.: Политиздат; 1991.

40. Крушинский ЛВ. Биологические основы рассудочной деятельности: эволюционные и физиолого-генетические аспекты поведения. М.: Изд-во МГУ; 1986.

41. Лаверычева ИГ. Биосоциальная теория альтруизма и эгоизма. СПб.: Нестор; 2007.

42. Лаверычева ИГ. Альтруизм и эгоизм как основа нравственной определенности. Вестник Санкт-Петербургского ун-та (серия 6) 2008;1:196-208.

43. Ламсден Ч, Гушурст А. Геннокультурная коэволюция: человеческий род в становлении. Человек. 1991;(3):11-22.

44. Ламсден Ч. Нуждается ли культура в генах? В кн.: Эволюция. Познание. Культура. М.: ИФРАН; 1996. с. 22-46.

45. Леонтьев АН. Биологическое и социальное в психике человека. Проблемы развития психики: 4-е изд. М.: Изд-во МГУ; 1981. с. 193-218.

46. Ломброзо Ч. Преступный человек. М.: Эксмо; 2005. с. 189-92.

47. Лоренц К. Восемь смертных грехов цивилизованного человечества. В кн.: Оборотная сторона зеркала. М.: Республика; 1998.

48. Лоренц К. Агрессия (так называемое «зло»). М.: РИМИС; 2009.
49. Мак-Фарленд Д. Поведение животных: Психобиология, этология и эволюция. М.: Мир; 1988

50. Малых СБ, Егорова МС, Мешкова Т.А. Основы психогенетики. М.: Эпидавр; 1998.

51. Мамзин АС. Биология и современная культура. В кн.: Биология и культура. М.: Канон; 2004, с. 50-99.

52. Марков А. Найдено ключевое различие между человеческим и обезьяньим интеллектом. Элементы (13.09.2007): URL: http:/ elementy.ru/news/430584

53. Марков А. Гены управляют поведением, а поведение - генами. Элементы (12.11.2008): URL: http://elementy.ru/news/430913

54. Марков А. Окситоцин усиливает любовь к «своим», но не улучшает отношения к чужакам. Элементы URL: http://elementy.ru/novosti nauki/431346

55. Марков А. Размер мозга коррелирует с общительностью. Элементы. URL: http://elementy.ru/news/431614

56. Марков БВ. Диалектика телесного и духовного. В кн.: Диалектика. Творчество. Гуманизм. Л.: Изд-во ЛГУ; 1991. с. 40-57.

57. Марков БВ. Философская антропология. СПб.: Питер; 2008.

58. Марков БВ. Реквием сексуальному. В кн. (предисловие): Бодрийар Ж. Забыть Фуко. СПб.: Владимир Даль; 2000. с. 5-34.

59. Мечников ИИ. Пессимизм и оптимизм. М.: Советская Россия; 1989. с. 500-46.

60. Наумов НП, Карташев НН. Зоология позвоночных. Книга 2: Пресмыкающиеся, птицы, млекопитающие. М.: Высшая школа; 1979.

61. Никольский СА. Социобиология - биосоциология человека? В кн.: Буржуазная философская антропология XX века. М.: Наука; 1986. c. $176-87$

62. Палмер Дж, Палмер Л. Эволюционная психология. Секреты поведения Homo sapiens. М.: Прайм-Еврознак; 2003. URL: www.gumer. info/bibliotek Buks/Psihol/palmer/intro.php

63. Равич-Щербо ИВ, Марютина ТМ, Гавриш НВ, Мешкова ТА. Кросскультурное психогенетическое исследование личностных черт. В кн.: Психогенетика. М.: Академия; 2006. c. $248-65$

64. Равич-Щербо ИВ, Марютина ТМ, Григоренко ЕЛ. Психогенетика. М.: Аспект-Пресс; 2008.

65. Резникова ЖИ. Сравнительный анализ различных форм социального обучения у животных. Журнал общей биологии. 2004;65(2):136-52.

66. Резникова ЖИ. Интеллект и язык животных. Основы когнитивной этологии. М.: Академкнига; 2005.

67. Резникова ЖИ. Исследование орудийной деятельности как путь к интегральной оценке когнитивных возможностей животных. Журнал общей биологии. 2006;67(1):2-22.

68. Резникова ЖИ. Эволюционные и этологические аспекты общественного образа жизни у животных. Информационный вестник ВОГиС. 2007;11(2):290-306. 
69. Резникова ЖИ. Социальное обучение у животных. Природа. 2009;(5):3-12.

70. Родни ДА. Влияние теории эволюции и натурализма на современную этику. Доклад на сессии круглого стола 24-27 мая 2000 г. (г. Ялта): Мировоззрение и образ жизни: что мы оставим нашим детям? URL: http://www.scienceandapologetics.org/text/50.htm

71. Роуз С. Устройство памяти. От молекул к сознанию. М.: Мир; 1995.

72. Савельев СВ. Происхождение мозга. М.: ВЕДИ; 2005.

73. Симонов ПВ. Эмоциональный мозг. М.: Наука; 1981.

74. Симонов ПВ. Нейробиология индивидуальности. Природа. 1997;(3):81-9.

75. Смайлли Д. Социобиология и человеческая культура. В кн.: Эволюция, культура, познание. М.: РАН Институт философии; 1996. c. $128-38$.

76. Спенсер Г. Синтетическая философия. Киев: Ника-Центр; 1997.

77. Строганова ТА, Цетлин ММ, Малых СБ, Малаховская ЕВ. Биологические основы индивидуальных различий детей второго полугодия жизни. Физиология человека. 2000;(3):38-47.

78. Субботский ЕВ. Исследования проблем взаимопомощи и альтруизма в зарубежной психологии. Вопросы психологии. 1977;(1):164-74.

79. Сычев ММ. Психогенетика: биосоциальные основы поведения и индивидуальности человека. Смоленск: Универсум; 2001.

80. Тинберген Н. Социальное поведение животных. М.: Мир, 1993.

81. Фогель М., Мотульски А. Генетика человека Том. 3, Главы 7-8. М.: Мир; 1990.

82. Фрейд 3. Психология бессознательного. М.: Просвещение; 1989.

83. Фрейд 3. Введение в психоанализ. Лекции. М.: Наука; 1991. с. 275-86; 399-416.

84. Фромм Э. Анатомия человеческой деструктивности. М.: Республика; 1994.

85. Фромм Э. Гуманистический психоанализ. СПб.: Питер; 2002.

86. Фуко М. Пылающий разум. В кн.: Матрица безумия. М.: Алгоритм, Эксмо; 2006.

87. Фукс ББ. Молекулярная генетика альтруизма. Труды Клуба русскоязычных ученых штата Массачусетс. URL: http://www.russianscientist.org/files/archive/Medicina/2010 FUX23.pdf-C. 2.

88. Фукс ББ. Программирование генов мозга и проблема социального поведения человека. Бюллетень сибирской медицины. 2013;12(2):275-83.

89. Харбах Х. Биологическая эволюция и альтруистическое поведение. Социологический журн. 1997;(1-2):38-47.

90. Шипунова ОД. Критические точки социогенеза. СПб.: Изд-во СПбГУ; 2004, с. 169-83.

91. Эфроимсон ВП. Родословная альтруизма. Новый мир. 1961;(10):193-214.

92. Эфроимсон ВП. Генетика этики и эстетики. СПб.: Талисман; 1995.

93. Эфроимсон ВП. Генетика гениальности. М.: Тайдекс; 2002.
94. Юнг КГ. Аффект цивилизации. В кн.: Матрица безумия. М.: Алгоритм; 2006, с. 11-136.

95. Якобони М. Отражаясь в людях: почему мы понимаем друг друга. М.: Юнайтед Пресс; 2011. c. 61-5.

\section{Общий список литературы/Reference List}

1. Abulkhanova KA. O Sub'yekte Psikhicheskoy Deyatel'nosti. [On the Subject of Mental Activity]. Moscow: Nauka; 1973. (In Russ.)

2. Abulkhanova-Slavskaya KA. [Relationships between the individual and the social as a methodological principle of psychology personality]. In: Teoreticheskiye Problemy Psikhologii Lichnosti. Moscow: Nauka; 1974, c. 34-82. (In Russ.)

3. Aleksandrov AA. Psikhogenetika. Psikhogenetica. [Psychogenetics]. Saint-Petersburg: Piter; 2006. (In Russ.)

4. Blyakher LYa. Istoriya Biologiyi (s Nachala XX Veka do Nashikh Dney). [The History of Biology (from the Beginning of the XX Century to Our Days)]. Moscow: Nauka; 1975. (In Russ.)

5. Bogdanov IV, Lazarev SV, Anufriyenko SS, Chmykhov YeV, Usoltseva IV, Kalinina NV. Psikhologiya i pedagogika. [The Structure of the Psyche. Section 5.2: The Cognitive Theories of Motivation]. URL: http://www.kspu.ru/ffec/psych/ps5. html (In Russ.)

6. Bogoyavlenskiy YuK, Ulissova TN, Yarovaya IM, Yarygin VN. Biologiya. [Biology]. Moscow: Meditsina; 1985. (In Russ.)

7. Baudrillard J. Zabyt' Fuko. [Forget Foucault]. Saint Petersburg: Vladimir Dal; 2000. c. 5-37. (In Russ.)

8. Brushlinskiy AB. [On relationships between the biological and the social in the development of personality]. In: Teoreticheskiye Problemy Psikhologii Lichnosti. [The Theoretical Problems of Psychology of Personality]. Moscow: Nauka; 1974. c. 83-121. (In Russ.)

9. Butovskaya ML. Tayny Pola. Muzhchina i Zhenshchina v Zerkale Evolutsiyi. [The Secrets of Sex. Man and Woman in the Mirror of Evolution]. Fryazino: Vek-2; 2004. (In Russ.)

10. Butovskaya ML. [The human being and anthropoid apes: The lingual abilities and the possibilities of a dialogue]. Zoologicheskiy Zhurnal. 2005;84(1):149-57. (In Russ.)

11. Butovskaya ML. Evolutsionnyye Osnovy Agressii i Primireniya u Cheloveka. [The Evolutionary Basis of Aggression and Reconciliation of the Human Being]. URL: http://www.polit.ru/lectures/2009/02/12/butov.html (In Russ.)

12. Gavrilova TP. [An experimental investigation into empathy in early childhood and middle-school age]. Voprosy Psikhologii. 1974;(5):107114. (In Russ.)

13. Gavrilova TP. [The concept of empathy in foreign psychology]. Voprosy Psikhologiyi. 1975;(2):145-58. (In Russ.)

14. Gerlinskaya LA. Izmenchivost' Zhivotnykh po Stressovym Reaktsiyam. [Animals Variability by Stress Reactions]. PhD These. Novosibirsk: 1987. (In Russ.)

15. Gerlinskaya LA, Moshkin MP, Yevsikov VI. [Methodological approaches to assessment of 
stresses in wild mammals]. Ecologiya. 1993;(6):97100. (In Russ.)

16. Gyuyo ZhM. Vospitaniye i Nasledstvennost". Sotsiologicheskoye Issledovaniye. Moscow: LKI; 2007. (In Russ.)

17. Darwin Ch. O Vyrazhenii Emotsiy u Cheloveka i Zhivotnykh. Saint Petersburg: Piter Press; 2001. p. 8-43. (In Russ.)

18. Delgado J. Mozg i Soznaniye. Moscow: Mir; 1971. (In Russ.)

19. Dembovskiy Ya. Psikhologiya Obez’yan. [Psychology of Apes]. Moscow: Nauka; 1963. (In Russ.)

20. Dawkins RK. Egoistichnyi Gen. [The Selfish Gene]. Moscow: Mir; 1993. (In Russ.)

21. Dawkins RK. Rasshirennyi Fenotip. Dlinnaya ruka gena. [The Extended Phenotype. The Long Arm of the Gene]. Moscow: Astrel; 2010. (In Russ.)

22. Dol'nik VR. [Ethological Excursions in the Forbidden Gardens of Humanitarians]. Priroda. 1993;(2).

23. Yegorova MS, Zyryanova NM, Parshikova OV, P'yankova SD, Chertkova YuD. Genotip, Sreda, Razvitiye. [Genotype, Environment, and Development]. Moscow: Ob'yedinyennoye Gumanitarnoye Izdatelstvo; 2004. (In Russ.)

24. Yegorova MS. [Developmental studires in psychogenetics]. In: Psikhogenetika. Moscow: Akademiya; 2006. p. 181-97. (In Russ.)

25. Yefremov K, Yefremova N. Eti Bonobo Znayut Angliyskiy Poluchshe Nas! [Those Bonobos Know English Better Than We Do!]. URL: http://ethology.ru/persons/?id=59 (In Russ.)

26. Zhimulyev IF. Obshchaya i Molyekulyarnaya Genetika. [General and and Molecular Genetics]. Novosibirsk: Sibirskoye Universitetskoye Izdatelstvo, 2006. (In Russ.)

27. Zorina ZA, Poletayeva II, Reznikova ZhI. Osnovy Etologiyi i Genetiki Povedeniya. [Foundations of Ethology and Genetics of Behavior]. Moscow: Izdatelstvo MGU; 2002, c. 122-51. (In Russ.)

28. Zorina ZA, Poletayeva II. Elementarnoye Myshleniye Zhivotnykh. [Elementary Cognition in Animals]. Moscow: Aspect Press; 2002.

29. Zorina ZA, Svirnova AA. O Chyem Rasskazali «Govoryashchiye» Obez'yany. [What Have «Speaking» Apes Told Us About]. Moscow: Yazyki Slavyanskikh Kul'tur; 2006. (In Russ.)

30. Ivz L, Hit E, Martin N, Mayers H, Nil M, Kendler K, Kirk K, Kori L. [The Comparison of Biological and Cultural Inheritance of Personality and Social Attitudes]. In: Psikhogenetika Moscow: Akademiya; 2006, c. 338-81. (In Russ.)

31. Inge-Vechtomov SG. Genetika s Osnovami Selektsiyi. [Genetics and Foundations of Selection]. Moscow: Vysshaya Shkola; 1989. (In Russ.)

32. Isakova GK. [The three types of twins in the embryogenesis of mink (Mustela vison)]. Genetika. 2007;43(2):280-83. (In Russ.)

33. Chaylakhyana LM. Istoki Altruizma. [The Sources of Altruism]. URL: http://www.philosophy.nsc.ru/ shev/altruism.htm (In Russ.)

34. Kanayev II. Bliznetsy i Genetika. [Twins and Genetics]. Leningrad: Nauka; 1968. (In Russ.)
35. Kemerov BYe. Problema Lichnosti: Metodologiya Issledovaniya i Zhiznennyi Smysl. [The Problem of Personality: The Methodology of Studies and the Sense of Life]. Moscow: Politizdat; 1977. p. 181-92. (In Russ.)

36. Korochkin LI. [Ontogenesis, evolution, and genes]. Priroda. 2002;(7):10-9. (In Russ.)

37. Kosonogov V. Zerkal'nyye Neyrony: Kratkiy Nauchnyy Obzor. [The Mirror Neurons: A Short Scientific Review]. Rostov-na-Donu: Antey; 2009. (In Russ.)

38. Kropotkin PA. Vzaimopomoshch Kak Factor Evolutsii. [The Mutual Aid as a Factor of Evolution]. Moscow: Samoobrazovaniye; 2007.

39. Kropotkin PA. Etika. Moscow: Politizdat; 1991. (In Russ.)

40. Krushinskiy LV. Biologicheskiye Osnovy Rassudochnoy Deyatel'nosti: Evolutsionnyye i fFziologo-Geneticheskiye Aspekty Povedeniya. [The Biological Bases of Reasoning: Evolutionary, Physiological, and Genetic Aspects of Behavior]. Moscow: Izdatelstvo MGU; 1986. (In Russ.)

41. Laverycheva IG. Biosotsial'naya Teoriya Al'truizma i Egoizma. [Biosocial Theory of Altruism and Egoism]. Saint Petersburg: Nestor; 2007. (In Russ.)

42. Laverycheva IG. [Altruism and Egoism as a Basis of the Moral Determinacy]. Vestnik Sankt-Peterburgskogo. Universiteta Ser 6 . 2008;1:196-208. (In Russ.)

43. Lumsden Ch, Gushurst A. Gennokulturnaya Koevolutsiya: Chelovecheskiy Rod v Stanovleniyi. [Gene-Culture Coevolution: Humankind in the Making]. Chelovek. 1991;(3):11-22. (In Russ.)

44. Lumsden Ch.J. Does culture need genes? Ethology and Sociobiology. 1989;(10):11-28.

45. Leont'yev AN. Biologicheskoye i Sotsial'noye v Psikhike Cheloveka. Propblemy Razvitiyya Psikhiki. [The Biological and Social in Human Psyche. The Problems of Psyche Development]. Moscow: Izdatelstvo MGU; 1981; p. 193-218. (In Russ.)

46. Lombrozo Ch. Prestupnyi Chelovek. Moscow: Eksmo. p. 189-92. (In Russ.)

47. Lorents K. [The Eight Deadly Sins of Civilized Mankind]. In: Oborotnaya Storona Zerkala. Moscow: Respublika; 1998. (In Russ.)

48. Lorents K. Agressiya (Tak Nazyvayemoye "Zlo"). [Aggression (the So-Called "Evil")]. Moscow: RIMIS; 2009. (In Russ.)

49. Mak-Farlend D. Povedeniye Zhivotnykh: Psikhobiologiya, Etologiya i Evolutsiya. [The Behavior of Animals: Psychobiology, Ethology and Evolution]. Moscow: Mir; 1988. (In Russ.)

50. Malykh SB, Yegorova MS, Meshkova TA. Osnovy psikhogenetiki. [Foundations Psychogenetics]. Moscow: Epidavr, 1998. (In Russ.)

51. Mamzin AS. [Biology and Modern Culture]. In: Biologiya i Kul'tura [Biology and Culture]. Moscow: Kanon; 2004, p. 50-99. (In Russ.)

52. Markov A. Naydeno klyuchevoye razlichiye mezhdu chelovecheskim i obez'yan'yim intellektom. [A key difference between the human and ape intellect is found]. URL: http://elementy.ru/ news/430584._(In Russ.)

53. Markov A. Geny upravlyayut povedeniyem, a povedeniye - genami. [Genes Manage Behav- 
ior, and Behavior Manages Genes]. URL: http:// elementy.ru/news/430913 (In Russ.)

54. Markov A. Oksitotsin usilivayet lyubov k svoim, no ne uluchshayet otnosheniya k chuzhakam. [Oxytocin enhances love for the kin but it does not better attitudes aliens]. URL: http://elementy.ru/novosti nauki/431346

55. Markov A. Razmer mozga korreliruyet s obshchitel'nost'yu. [Brain size correlates with sociability]. URL: http://elementy.ru/news/431614. (In Russ.)

56. Markov BV. [Dialectics of the Bodily and the Spiritual] In: Dialektika. Tvorchestvo. Gumanizm. [Dialectics. Creativity. Humanism]. Leningrad: Izdatelstvo LGU; 1991, p. 40-57. (In Russ.)

57. Markov BV. Filosofskaya Antropologiya [Philosophical Anthropology]. Saint Petersburg: Piter Press; 2008. (In Russ.)

58. Markov BV. Rekviem Seksual'nomu. [Requiem for Sexuality]. In (Preface): Bodriyar Zh. Zabyt Fuko. Saint Petersburg: Vladimir Dal; 2000, p. 5-34. (In Russ.)

59. Mechnikov II. Pessimizm i Optimizm. [Pessimism and Optimism]. Moscow: Sovetskaya Rossiya; 1989, p. 500-46. (In Russ.)

60. Naumov NP, Kartashev NN. Zoologiya Pozvonochnykh. Kniga 2.: Presmykayushchiyesya, Ptitsy, Mlekopitayushchiye. [Zoology of the Vertebrates. Book 2: Reptiles, Birds, Mammals]. Moscow: Vysshaya Shkola; 1979.

61. Nikol'skiy SA. [Sociobiology: The Biosociology of Humans?] In: Burzhuaznaya Filosofskaya Antropologiya XX Veka. [Bourgeois Philosophic Anthropology of the XX Century]. Moscow: Nauka; 1986, p. 176-87.

62. Palmer Dzh, Palmer L. Evolutsionnaya Psikhologiya. Sekrety Povedeniya Homo sapiens. [Evolutionary Psychology. The Secrets of the Behavior of Homo sapiens]. Moscow: Praym-Yevroznak; 2003.

63. Ravich-Shcherbo IV, Maryutina TM, Gavrish NV, Мешкова TA. [Cross-cultural Psychogenetical Study of Personal Traits]. In: Psikhogenetika [Psychogenetics]. Moscow: Akademiya; 2006. c. 248-65. (In Russ.)

64. Ravich-Shcherbo IV, Maryutina TM, Grigorenko YeL. Psikhogenetika. [Psychogenetics]. Moscow: Aspekt-Press; 2008. (In Russ.)

65. Reznikova ZhI. [Comparative analysis of different forms of animal's social learning]. Zhurnal Obshchey Biologiyi. 2004;65(2):136-52. (In Russ.)

66. Reznikova ZhI. Intellekt i Yazyk Zhivotnykh. Osnovy Kognitivnoy Etologii. [The Intellect and the Language of Animals. The Basics of Cognitive Ethology]. Moscow: Aкаdemkniga; 2005. (In Russ.)

67. Reznikova ZhI. [Study using tools as an approach to the general assessment of cognitive abilities in animals]. Zhurnal Obshchey Biologii. 2006; 67(1):2-22. (In Russ.)

68. Reznikova ZhI. [Evolutionary and behavioral aspects of social life in animals]. Informatsionnyy Vestnik VOGiS 2007;11(2):290-306. (In Russ.)

69. Reznikova ZhI. [The Social Training of Animals]. Priroda. 2009;(5):3-12. (In Russ.)
70. Rodni DA. [The imact of the theory of evolution and of natural sciences on modern ethics]. URL: http://www.scienceandapologetics.org/ text/50.htm. (In Russ.)

71. Rouz S. Ustroystvo Pamyati. Ot Molekul k Soznaniyu. [The Design of Memory. From Molecules to the Consciousness]. Moscow: Mir; 1995. (In Russ.)

72. Savel'ev SV. Proiskhozhdeniye Mozga. [The Origin of the Brain]. Moscow: VEDI; 2005.

73. Simonov PV. Emotsional'nyi Mozg. [The Emotional Brain]. Moscow: Nauka; 1981.

74. Simonov PV. Neyrobiologiya Individual'nosti. [Neurobiology of Individuality]. Priroda. 1997;(3):81-9. (In Russ.)

75. Smaylli D. [Sociobiology and Human Culture]. In: Evolutsiya, Kultura, Poznaniye. [Evolution, Culture, and Learning]. Moscow: Institut Filosofiii RAN; 1996, c. 128-38. (In Russ.)

76. Spencer G. Sinteticheskaya Filosofiya. [The Synthetic Philosophy]. Kiyev: Nika-Tsentr; 1997. (In Russ.)

77. Stroganova TA, Tsetlin MM, Malykh SB, Malakhovskaya YeV. [The biological basis of individual differences between children of the second half-year of life]. Fiziologiya Cheloveka. 2000; (3):38-47. (In Russ.)

78. Subbotskiy YeV. [Study of problems of mutual help and altruism in foreign psychology]. Voprosy psikhologii. 1977;(1):164-74. (In Russ.)

79. Sychev MM. Psikhogenetika: Biosotsial'nyye Osnovy Povedeniya i Individual'nosti Cheloveka. [Psychogenetics: The Biosocial Bases of Human Behavior and Individuality]. Smolensk: Universum; 2001. (In Russ.)

80. Tinbergen N. Social Behavior in Animals. New York: Wiley; 1953.

81. Fogel M, Motulski A. Genetika Cheloveka. Tom 3.

82. Freyd Z. Psikhologiya Bessoznatel'nogo. [Psychology of Unconscious]. Moscow: Prosveshcheniye; 1989. (In Russ.)

83. Freyd Z. Vvedeniye v Psikhoanaliz. Lektsiyi. [Introduction into Psychoanalysis. Lectures]. Moscow: Nauka; 1991, p. 275-86; 399-416. (In Russ.)

84. Fromm E. Anatomiya Chelovecheskoy Destruktivnosti. [Anatomy of Human Destructiveness]. Moscow: Respublika; 1994. (In Russ.)

85. Fromm E. Gumanisticheskiy Psikhoanaliz. [Humanistic Psychoanalysis]. Saint Petersburg: Piter Press; 2002. (In Russ.)

86. Fuko M. [The Flaming Mind]. In: Matritsa Bezumiya. Moscow: Algoritm, Eksmo; 2006. (In Russ.)

87. Fuks BB. Molekulyarnaya Genetika Altruizma. [The Molecular Genetics of Altruism]. URL: http://russianscientist.org/files/archive/Medicina/2010 FUX-23.pdf. (In Russ.)

88. Fuks BB. [The programming of brain genes and the problem of human Social behavior]. Byulleten' Sibirskoy Meditsiny. 2013;12(2):275-83. (In Russ.)

89. Kharbakh Kh. [The biological evolution and the altruistic behavior]. Sotciologicheskiy Zhurnal. 1997;(1-2):38-47. (In Russ.) 
90. Shipunova OD. Kriticheskiye Tochki Sotsiogeneza. [The Critical Points of Sociogenesis]. Saint Petersburg: Izdatelstvo SPbGU; 2004, p. 169-83. (In Russ.)

91. Efroimson VP. [The genealogy of altruism]. Novyi Mir. 1961;(10):193-214. (In Russ.)

92. Efroimson VP. Genetika Etiki i Estetiki. [The Genetics of Ethics and Aesthetics]. Saint Petersburg: Talisman; 1995. (In Russ.)

93. Efroimson VP. Genetika Genial'nosti. [The Genetics of Geniality]. Moscow: Taydeks; 2002. (In Russ.)

94. Yung KG. [The affection of civilization]. In: Matritsa Bezumiya. Moscow: Algoritm, Eksmo; 2006, p. 11-136. (In Russ.)

95. Yakoboni M. Otrazhayas' v Lyudyakh: Pochemu My Ponimayem Drug Druga. [Reflecting in People: Why do We Understand One Another]. Moscow: United Press; 2011, p. 61-5. (In Russ.)

96. Barrett L, Henzi P, Weingrill T. Female baboons do not raise the stakes but they give as good as they get. Animal Behaviour. 2000;59:763-70.

97. Dawkins MS. Self-awareness in primates. Amer Sci. 1979;(67):417-21.

98. Dawkins MS. Animal Suffering. London: Chapman and Hall; 1980.

99. Dawkins MS. The science of animal suffering. Ethology. 2008;114(10):937-45.

100. De Dreu CKW, Greer LL, Handgraaf MJJ, Shalvi S, Van Kleef GA, Baas M, Velden FST, Van Dijk E, Feith SWW. The neuropeptide oxytocin regulates parochial altruism in intergroup conflict among humans. Science. 2010;328:1408-11.

101. Fisher RA. The Genetical Theory of Natural Selection. Clarendon Press; 1930.

102. Gluth S, Fontanesi L. Wiring the altruistic brain. Science. 2016;351:1028-9.

103. Hamilton WD. The genetical evolution of social behavior. J Theor Biol. 1964;(7):1-32.

104. Hamilton WD. Innate Social Aptitudes of Man: an Approach from Evolutionary Genetics. Biosocial Anthropology. London: Malaby; 1975, p. 1-169.

105. Hein G, Morishima Y, Leiberg S, Sul S, Fehr E. The brain's functional network architecture reveals human motives. Science. 2016;351:1074-8.

106. Herrmann E, Call J, Hernàndez-Lloreda M, Hare B, Tomasello M. Humans have evolved specialized skills of social cognition: The cultura intelligence hypothesis. Science. 2007;317:360-6.

107. Horváth K, Martos J, Mihalik B, Bódizs $\mathrm{R}$. Is the social brain theory applicable to human individual differences? Relationship between sociability personality dimension and brain size. Evolutionary Psychology. 2011;9:244-56.

108. Israel I, Hasenfratz L, Knafo-Noam A. The genetics of morality and prosociality. Curr Opin in Psychol. 2015;6:55-9.

109. Israel S, Lerer E, Shalev I, Uzefovsky F, Riebold M, Laiba E, Bachner-Melman R, Maril A, Bornstein G, Knafo A, Ebstein R. The oxytocin receptor (OXTR) contributes to prosocial gund allocations in the dictator game and the social value orientations task. PLoS ONE. 2009; 4(5):e5535. http://dx.doi.org/10.1371/journal.pone.0005535
110. Knafo A, Israel S, Darvasi A et al. Individual differences in allocation of funds in the dictator game associated with length of the arginine vasopressin 1a receptor RS3 promoter region. Genes Brain Behav. 2008;7(3):266-5.

111. Koenigs M, Tranel D. Irrational economic decision-making after ventromedial prefrontal damage: Evidence from the ultimatum Game. J Neurosci. 2007;27(4):951-6.

112. Lorenz K. Evolution and Modification of Behaviour. London. 1965.

113. Lovejoy CO. The origin of man. Science. 1981;211(4480):341-50.

114. Lovejoy CO. Reexamining human origins in light of Ardipithecus ramidus. Science. 2009;326:741-8.

115. Lumsden CJ, Wilson EJ. Genes, Mind and Culture: The Coevolutionary Process. Cambridge; 1981.

116. Maynard Smith J. Group selection and kin selection. Nature. 1964;201:1145-7.

117. Maynard Smith J. Sexual selection and the handicap principle. J Theor Biol. 1974;57:239-42.

118. Maynard Smith J. Evolution and the Theory of Games. Cambridge: University Press; 1982.

119. Melis A, Hare B, Tomasello M. Chimpanzees recruit the best Collaborators. Science. 2006;311:1297-300

120. Prato-Previde E, Fallani G, Valsecchi P. Gender differences in owners inter-acting with pet dogs: An observational study. Ethology. 2006;112(1):64-73.

121. Read DW. Working memory: A cognitive limit to non-human primate recursive thinking prior to hominid evolution. Evolutionary Psychology. 2008;6:676-714.

122. Reuter M, Frenzel C, Walter NT, Markett $\mathrm{S}$, Montag C. Investigating the genetic basis of altruism: the role of the COMT Val158Met polymorphism. Soc Cogn Affect Neurosci. 2011;6:662-8.

123. Roth E, Dicke U. Evolution of the brain and intelligence. Trends Cognitive Sci. 2005;9(5):250-7.

124. Sinervo B. Runaway social games, genetic cycles driven by alternative male and female strategies, and the origin of morphs. Genetica. 2001;(112-113):417-34.

125. Sternberg RJ. Handbook of Human Intelligence. Cambridge; London; New York: Cambridge University Press; 1982.

126. Thompson GJ, Hurd PL, Crespi BJ. Genes underlying altruism. Biol Lett. 2013. URL: http:// dx.doi.org/10.1098/rsbl.2013.0395

127. Trivers RL. The evolution of reciprocal altruism. Quart Rev Biol. 1971;46:35-57.

128. Warneken F, Tomasello M. Altruistic helping in human infants and young chimpanzees. Science. 2006;311:1301-3.

129. Wilson EO. Sociobiology: The New Synthesis. Cambridge: The Belknap Press of Harvard Univ.; 1975.

130. Wilson EO. The Genetic Evolution of Altruism. London, 1978.

131. Wilson EO. On Human Nature. Cambridge Mass.; 1978.

132. Wilson EO. Biologie als Schicksal. Frankfurt; 1980. 